\title{
Global $\mathrm{O}_{3}-\mathrm{CO}$ correlations in a chemistry and transport model during July-August: evaluation with TES satellite observations and sensitivity to input meteorological data and emissions
}

\author{
Hyun-Deok Choi ${ }^{1}$, Hongyu Liu ${ }^{1}$, James H. Crawford ${ }^{2}$, David B. Considine ${ }^{2, a}$, Dale J. Allen ${ }^{3}$, Bryan N. Duncan ${ }^{4}$, \\ Larry W. Horowitz ${ }^{5}$, Jose M. Rodriguez ${ }^{4}$, Susan E. Strahan ${ }^{4,6}$, Lin Zhang ${ }^{7, b}$, Xiong Liu ${ }^{7}$, Megan R. Damon ${ }^{4,8}$, and \\ Stephen D. Steenrod ${ }^{4,6}$ \\ ${ }^{1}$ National Institute of Aerospace, Hampton, VA, USA \\ ${ }^{2}$ NASA Langley Research Center, Hampton, VA, USA \\ ${ }^{3}$ University of Maryland, College Park, MD, USA \\ ${ }^{4}$ NASA Goddard Space Flight Center, Greenbelt, MD, USA \\ ${ }^{5}$ NOAA Geophysical Fluid Dynamics Laboratory, Princeton, NJ, USA \\ ${ }^{6}$ Universities Space Research Association, Columbia, MD, USA \\ ${ }^{7}$ Harvard University, Cambridge, MA, USA \\ ${ }^{8}$ Science Systems and Applications, Inc., Lanham, MD, USA \\ ${ }^{a}$ now at: NASA Headquarters, Washington, D.C., USA \\ ${ }^{b}$ now at: Peking University, Beijing, China \\ Correspondence to: Hongyu Liu (hongyu.liu-1@ @asa.gov)
}

Received: 1 December 2016 - Discussion started: 17 January 2017

Revised: 16 May 2017 - Accepted: 29 May 2017 - Published: 11 July 2017

\begin{abstract}
We examine the capability of the Global Modeling Initiative (GMI) chemistry and transport model to reproduce global mid-tropospheric $(618 \mathrm{hPa})$ ozone-carbon monoxide $\left(\mathrm{O}_{3}-\mathrm{CO}\right)$ correlations determined by the measurements from the Tropospheric Emission Spectrometer (TES) aboard NASA's Aura satellite during boreal summer (JulyAugust). The model is driven by three meteorological data sets (finite-volume General Circulation Model (fvGCM) with sea surface temperature for 1995, Goddard Earth Observing System Data Assimilation System Version 4 (GEOS4 DAS) for 2005, and Modern-Era Retrospective Analysis for Research and Applications (MERRA) for 2005), allowing us to examine the sensitivity of model $\mathrm{O}_{3}-\mathrm{CO}$ correlations to input meteorological data. Model simulations of radionuclide tracers $\left({ }^{222} \mathrm{Rn},{ }^{210} \mathrm{~Pb}\right.$, and $\left.{ }^{7} \mathrm{Be}\right)$ are used to illustrate the differences in transport-related processes among the meteorological data sets. Simulated $\mathrm{O}_{3}$ values are evaluated with climatological profiles from ozonesonde measurements and satellite tropospheric $\mathrm{O}_{3}$ columns. Despite the fact that the three simulations show significantly different global
\end{abstract}

and regional distributions of $\mathrm{O}_{3}$ and $\mathrm{CO}$ concentrations, they show similar patterns of $\mathrm{O}_{3}-\mathrm{CO}$ correlations on a global scale. All model simulations sampled along the TES orbit track capture the observed positive $\mathrm{O}_{3}-\mathrm{CO}$ correlations in the Northern Hemisphere midlatitude continental outflow and the Southern Hemisphere subtropics. While all simulations show strong negative correlations over the Tibetan Plateau, northern Africa, the subtropical eastern North Pacific, and the Caribbean, TES $\mathrm{O}_{3}$ and $\mathrm{CO}$ concentrations at $618 \mathrm{hPa}$ only show weak negative correlations over much narrower areas (i.e., the Tibetan Plateau and northern Africa). Discrepancies in regional $\mathrm{O}_{3}-\mathrm{CO}$ correlation patterns in the three simulations may be attributed to differences in convective transport, stratospheric influence, and subsidence, among other processes. To understand how various emissions drive global $\mathrm{O}_{3}-\mathrm{CO}$ correlation patterns, we examine the sensitivity of GMI/MERRA model-calculated $\mathrm{O}_{3}$ and $\mathrm{CO}$ concentrations and their correlations to emission types (fossil fuel, biomass burning, biogenic, and lightning $\mathrm{NO}_{x}$ emissions). Fossil fuel and biomass burning emissions are mainly responsible for 
the strong positive $\mathrm{O}_{3}-\mathrm{CO}$ correlations over continental outflow regions in both hemispheres. Biogenic emissions have a relatively smaller impact on $\mathrm{O}_{3}-\mathrm{CO}$ correlations than other emissions but are largely responsible for the negative correlations over the tropical eastern Pacific, reflecting the fact that $\mathrm{O}_{3}$ is consumed and $\mathrm{CO}$ generated during the atmospheric oxidation process of isoprene under low- $\mathrm{NO}_{x}$ conditions. We find that lightning $\mathrm{NO}_{x}$ emissions degrade both positive correlations at mid- and high latitudes and negative correlations in the tropics because ozone production downwind of lightning $\mathrm{NO}_{x}$ emissions is not directly related to the emission and transport of $\mathrm{CO}$. Our study concludes that $\mathrm{O}_{3}-\mathrm{CO}$ correlations may be used effectively to constrain the sources of regional tropospheric $\mathrm{O}_{3}$ in global 3-D models, especially for those regions where convective transport of pollution plays an important role.

\section{Introduction}

Ozone $\left(\mathrm{O}_{3}\right)$ is an important greenhouse gas in the troposphere and a pollutant at the surface. It is a primary source of the hydroxyl radical $(\mathrm{OH})$, which controls the oxidizing power of the troposphere. Ozone in the troposphere is produced by photochemical oxidation of carbon monoxide (CO), methane, and volatile organic hydrocarbons (VOCs) in the presence of nitrogen oxides $\left(\mathrm{NO}_{x} \equiv \mathrm{NO}+\mathrm{NO}_{2}\right)$. Its precursors are emitted by human activity (e.g., fossil fuel combustion and industrial processes), biomass burning, vegetation, soils, and lightning. Ozone is also transported down from the stratosphere by the Brewer-Dobson circulation. Carbon monoxide is a product of incomplete combustion. Its sources include fossil fuel and biofuel combustion; biomass burning; and chemical production from atmospheric oxidation of methane, isoprene, and other VOCs. Its primary sink is reaction with $\mathrm{OH}$.

Since $\mathrm{CO}$ is a precursor of tropospheric $\mathrm{O}_{3}$ and an excellent tracer for long-range transport of pollution owing to its tropospheric lifetime of a few months, correlations between $\mathrm{O}_{3}$ and $\mathrm{CO}$ are useful indicators of the efficiency of $\mathrm{O}_{3}$ production and export (e.g., Parrish et al., 1993; Mao and Talbot, 2004). Generally, a positive correlation in summer indicates strong photochemical production of $\mathrm{O}_{3}$ downwind of polluted regions (Chin et al., 1994; Tsutsumi and Matsueda, 2000). A negative correlation indicates stratospheric influence (Parrish et al., 1998; Hsu et al., 2004), photochemical $\mathrm{O}_{3}$ destruction (Fishman and Seiler, 1983; Parrish et al., 1998; Mao and Talbot, 2004), or chemical production of CO (Chin et al., 1994; Real et al., 2008). Small correlation coefficients and small linear regression slopes are indications of fresh pollution plumes that have not yet realized their $\mathrm{O}_{3}$ production potential due to, for example, incomplete photochemical processes (Naja et al., 2003).
Many studies have used surface- and/or aircraft-observed $\mathrm{O}_{3}-\mathrm{CO}$ correlations to understand anthropogenic influences on $\mathrm{O}_{3}$, especially in the Northern Hemisphere $(\mathrm{NH})$ continental outflow regions such as the northeastern US/North Atlantic (Fishman and Seiler, 1983; Anderson et al., 1993; Parrish et al., 1993; Chin et al., 1994; Fehsenfeld et al., 1996; Parrish et al., 1998; Li et al., 2002; Honrath et al., 2004; Mao and Talbot, 2004) and the Asian Pacific Rim (Tsutsumi and Matsueda, 2000; Mauzerall et al., 2000). The studies found strong $\mathrm{O}_{3}-\mathrm{CO}$ correlations in outflow regions and concluded that the export of pollution from the $\mathrm{NH}$ major continents makes a significant contribution to total tropospheric $\mathrm{O}_{3}$ over the $\mathrm{NH}$ during summer.

The observed $\mathrm{O}_{3}-\mathrm{CO}$ correlation coefficients and linear regression slopes have been used to evaluate the capability of chemistry and transport models (CTMs) to produce proper $\mathrm{O}_{3}$ levels from its precursors for the right reasons (e.g., Chin et al., 1994; Mauzerall et al., 2000; Zhang et al., 2006; Voulgarakis et al., 2011). Shim et al. (2009) examined the Mexico City pollution outflow using $\mathrm{O}_{3}, \mathrm{CO}$, and their correlations from TES as well as aircraft measurements obtained during the Megacity Initiative: Local and Global Research Observations (MILAGRO) and Intercontinental Chemical Transport Experiment (INTEX-B) campaigns. These investigations found that TES data are characterized by smaller $\mathrm{O}_{3}-\mathrm{CO}$ correlation coefficients but larger linear regression slopes than in situ observations at $618 \mathrm{hPa}$ partly due to the lack of variability in TES CO. Two previous studies also examined TES global $\mathrm{O}_{3}-\mathrm{CO}$ correlations. Zhang et al. (2006) compared mid-tropospheric TES O ${ }_{3}-$ CO correlations in July 2005 over the eastern United States with those from the GEOS-Chem (Goddard Earth Observing System-Chemistry) CTM and International Consortium for Atmospheric Research on Transport and Transformation (ICARTT) aircraft observations (July 2004), finding that TES can provide good information on global mid-tropospheric $\mathrm{O}_{3}-\mathrm{CO}$ correlations. Voulgarakis et al. (2011) expanded the scope of Zhang et al. (2006), evaluating $\mathrm{O}_{3}-\mathrm{CO}$ correlations simulated by two independent models against 5 years of TES observations. They suggested that, in addition to $\mathrm{O}_{3}$ photochemical processes, transport may also play an important role in the $\mathrm{O}_{3}-\mathrm{CO}$ correlations. However, Voulgarakis et al. (2011) could not isolate the effect of transport because the two models in their study used different input meteorological data sets as well as different chemical and transport mechanisms.

In this paper, we present $\mathrm{O}_{3}$ and $\mathrm{CO}$ simulations using the Global Modeling Initiative (GMI) CTM driven by three meteorological data sets. The model can incorporate different inputs and components (e.g., meteorological fields, emission inventories, and chemical mechanisms), allowing us to test the sensitivity of model simulations to input meteorological data sets (e.g., Douglass et al., 1999; Considine et al., 2005; Liu et al., 2016). Model simulations are evaluated using ozonesonde and satellite observations. We then test the 
model's capability to reproduce the mid-tropospheric $\mathrm{O}_{3}-$ $\mathrm{CO}$ correlations determined from TES measurements. We present the differences in the simulated $\mathrm{O}_{3}-\mathrm{CO}$ correlations due to the use of different meteorological input data and interpret those differences in terms of transport using radionuclide species $\left({ }^{222} \mathrm{Rn},{ }^{210} \mathrm{~Pb}\right.$, and $\left.{ }^{7} \mathrm{Be}\right)$ as tracers of atmospheric transport (see Sect. 2.1.3). We also investigate the effect of emission types on $\mathrm{O}_{3}$ and $\mathrm{CO}$ concentrations and their correlations in the model.

This paper is organized as follows: Sect. 2: descriptions of the GMI model, meteorological data sets, and observational data sets; Sect. 3: presentation of the model simulations of radionuclides, $\mathrm{O}_{3}$, and $\mathrm{CO}$; Sect. 4: evaluation of GMI $\mathrm{O}_{3}$ and $\mathrm{CO}$ simulations with observations; Sect. 5: evaluation of $\mathrm{GMI} \mathrm{O}_{3}-\mathrm{CO}$ correlations with satellite observations from TES; Sect. 6: analysis of the effects of various emission types on the model-simulated $\mathrm{O}_{3}-\mathrm{CO}$ correlations; and Sect. 7: summary and conclusions.

\section{Model and data}

\subsection{GMI}

\subsubsection{The CTM}

The GMI CTM is a global 3-D composition model that combines both tropospheric and stratospheric chemical mechanisms, including 124 species, 322 chemical reactions, and 81 photolysis reactions (Ziemke et al, 2006; Duncan et al., 2007a; Considine et al., 2008; Allen et al., 2010). The tropospheric mechanism includes a detailed description of tropospheric $\mathrm{O}_{3}-\mathrm{NO}_{x}$-hydrocarbon chemistry (Bey et al., 2001) with recent updates (e.g., see Allen et al., 2010). The stratospheric mechanism is described in Kinnison et al. (2001) and Douglass et al. (2004). The details of the GMI model are described in Duncan et al. (2007a) and Strahan et al. (2007). The basic structure of the model is described in Rotman et al. (2001).

The GMI model uses a flux-form semi-Lagrangian (FFSL) advection scheme (Lin and Rood, 1996) and also includes parameterizations of convection, wet scavenging, dry deposition, and planetary boundary layer mixing. The anthropogenic emission (e.g., fossil fuel emissions) scheme is from Bey et al. (2001), Benkovitz et al. (1996), and Duncan et al. (2007b). We use the anthropogenic emission inputs for 2005 for all simulations in this study. The biogenic emission scheme is calculated online based on Guenther et al. (2006), and biofuel emissions are estimated from the inventory and emission factors of Yevich and Logan (2003). Biomass burning emissions are from Duncan et al. (2003) climatology, where the spatial and seasonal variability are derived from satellite observations of monthly total fire counts. Lightning $\mathrm{NO}_{x}$ emissions are calculated locally in deep-convection events with the scheme of Allen et al. (2010), where flash rates are assumed to be proportional to the square of upward convective mass flux but constrained by monthly average climatological flash rates from V2.2 of the Optical Transient Detector (OTD) and the Lightning Imaging Sensor (LIS) climatology. GMI uses modules developed at Harvard University to calculate rates of wet scavenging (Mari et al., 2000; Liu et al., 2001) and dry deposition (Jacob and Wofsy, 1990).

Several studies have previously evaluated the GMI CTM simulations of tropospheric $\mathrm{O}_{3}$ and $\mathrm{CO}$. Ziemke et al. (2006) compared the tropospheric ozone columns (TOCs) in an earlier version of the GMI CTM, which was driven by the finite-volume General Circulation Model (fvGCM) meteorological fields (details in Sect. 2.1.2), with those determined from Ozone Monitoring Instrument (OMI) and Microwave Limb Sounder (MLS) measurements from the NASA Aura satellite. The comparison showed similarities with respect to zonal and seasonal variations of TOC, but the model overestimated TOC over northern Africa by as much as $10 \mathrm{DU}$, likely due to desert dust effects, while underestimating TOC over the western Pacific warm pool by up to 10 DU. Chandra et al. (2009) evaluated GMI TOC when driven by the GEOS4 meteorological fields (see Sect. 2.1.2) with OMI/MLS TOC and found the model overestimated TOC by $5-10 \mathrm{DU}$ for the latitude band $30-35^{\circ} \mathrm{N}$ all the year and over east China in winter and spring, when stratosphere-troposphere exchange (STE) is greatest. Duncan et al. (2008) showed that the annual average surface $\mathrm{O}_{3}$ concentrations in the GMI/GEOS-4 simulation had a high bias of about $11 \%$, with higher biases in summer, when photochemical production is the dominant source of $\mathrm{O}_{3}$. Considine et al. (2008) examined the ability of GMI/fvGCM $\left(4^{\circ} \times 5^{\circ}\right)$ to represent the observed neartropopause $\mathrm{O}_{3}$ distributions and found that annual mean $\mathrm{O}_{3}$ concentrations were biased high by $45 \%$ at the model thermal tropopause likely due to insufficient vertical resolution near the tropopause $(\sim 1.1 \mathrm{~km})$ and/or too-high vertical diffusivity.

For CO, Duncan et al. (2007a) compared GMI/fvGCMsimulated tropospheric CO concentrations with NOAA Global Monitoring Division (GMD) surface observations. They showed that the model was biased low at most sites in local winter-spring, likely due to overestimation of $\mathrm{OH}$ in the simulation, when the $\mathrm{CO}$ burden is typically at an annual maximum. Schoeberl et al. (2006) showed that GMI/fvGCM was able to reproduce the uppertroposphere/lower-stratosphere (UT/LS) CO tape recorder caused by seasonal changes in biomass burning, as identified with the MLS data.

\subsection{2 fvGCM, GEOS-4, and MERRA meteorological data sets}

We drive the GMI CTM with three meteorological data sets from the free-running NASA Global Modeling and Assimilation Office (GMAO) fvGCM with sea surface temperature for 1995, the Goddard Earth Observing System Data Assim- 
ilation System Version 4 (GEOS-4 DAS) for 2005, and the Modern-Era Retrospective Analysis for Research and Applications (MERRA) for 2005. Note that the fvGCM is the general circulation model in the assimilation system used to generate GEOS-4 DAS (Bloom et al., 2005). The native vertical coordinate of fvGCM and GEOS-4 DAS models is a generalized hybrid sigma-pressure coordinate system with 55 vertical layers and a smooth transition between sigma in the troposphere (pressure $>200 \mathrm{hPa}$ ) and pure pressure in the stratosphere (top pressure: $0.01 \mathrm{hPa}$ ). MERRA is a NASA atmospheric reanalysis data set from a new version of GEOS DAS Version 5 (GEOS-5.2.0). GEOS-5 is a system of models integrated using the Earth System Modeling Framework (ESMF). Compared to GEOS-4, GEOS-5 adopts an analysis system developed jointly with the National Centers for Environmental Prediction (NCEP) and a different set of physics packages for the atmospheric GCM. MERRA has 72 vertical levels with a lid at $0.01 \mathrm{hPa}$ (sigma-pressure coordinate interface at $\sim 177 \mathrm{hPa}$ ). The native horizontal resolution of all meteorological data sets is $1^{\circ} \times 1.25^{\circ}$. To improve computational efficiency, we drive the GMI CTM with the meteorological data sets at a degraded resolution $\left(2^{\circ}\right.$ latitude by $2.5^{\circ}$ longitude). All standard and perturbation full-chemistry simulations for July-August as presented in this paper were conducted with a 6-month spin-up.

The different convective parameterizations used to generate the meteorological data sets alter the characteristics of convective transport of chemical species. Both fvGCM and GEOS-4 use the deep-convection scheme of Zhang and McFarlane (1995) and the shallow-convection scheme of Hack (1994), whereas MERRA uses a modified version of the relaxed Arakawa-Schubert (RAS) scheme for convection (Moorthi and Suarez, 1992). Figure 1 shows the latitudepressure cross sections of zonal mean convective mass fluxes averaged over three meteorological data fields and the differences from the average during July-August. fvGCM shows the strongest shallow convection at Southern Hemisphere (SH) mid- and low latitudes among the models. GEOS-4 shows the strongest convection in the tropical middle troposphere (MT). MERRA is characterized by the weakest shallow convection in both hemispheres. MERRA has the strongest tropical convection in the lower free troposphere, but its tropical convection is not as deep as in the others. Shallow convection in fvGCM and GEOS-4 extends to higher latitudes than in MERRA.

\subsubsection{Radionuclide tracers}

We conduct GMI model simulations of radionuclides $\left({ }^{222} \mathrm{Rn}\right.$, ${ }^{210} \mathrm{~Pb}$, and ${ }^{7} \mathrm{Be}$ ) to examine the relative effects of convection, stratospheric influence, and large-scale subsidence on the transport of trace species and their sensitivity to input meteorological data sets. ${ }^{222} \mathrm{Rn}$ has a half-life of 3.8 days and is emitted primarily from continental crust. It is useful as a tracer of convective transport in global models (e.g., Jacob et

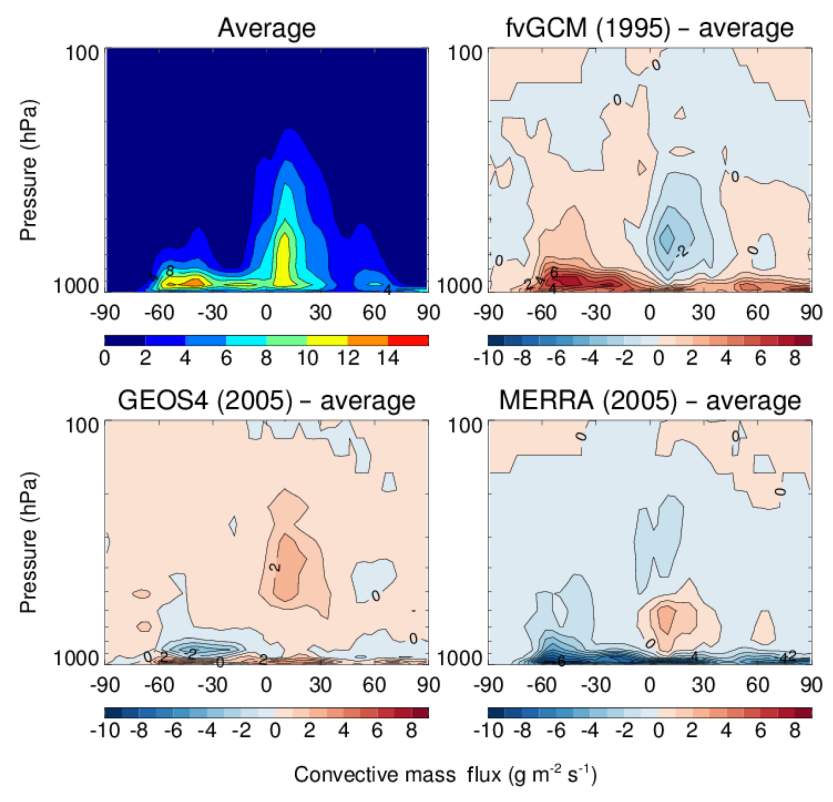

Figure 1. Latitude-pressure cross sections of zonal mean convective mass fluxes during July-August. The plot shows the values averaged over the fvGCM (1995), GEOS-4 (2005), and MERRA (2005) meteorological data sets, as well as differences from the average.

al., 1997). ${ }^{210} \mathrm{~Pb}$, a decay daughter of ${ }^{222} \mathrm{Rn}$, has a radioactive half-life of 22.3 years, and ${ }^{7} \mathrm{Be}$, which is produced by cosmic ray spallation reactions in the stratosphere and UT, has a radioactive half-life of 53.3 days. Because ${ }^{210} \mathrm{~Pb}$ and ${ }^{7} \mathrm{Be}$ attach to submicron aerosols after production and are therefore scavenged by precipitation or deposited to the surface, they have been used as a pair to test wet-deposition schemes in global models (e.g., Liu et al., 2001). ${ }^{7} \mathrm{Be}$ is also used as a tracer for STE (Dibb et al., 1994; Liu et al., 2001, 2016). The ratio ${ }^{7} \mathrm{Be} /{ }^{210} \mathrm{~Pb}$ is useful as an indicator of vertical transport because the ratio is insensitive to precipitation scavenging (Koch et al., 1996). All simulations of radionuclide tracers were conducted with a 5 -year spin-up in order for ${ }^{210} \mathrm{~Pb}$ to reach an equilibrium in the stratosphere.

\subsection{Data sets}

\subsubsection{Ozonesonde $\mathrm{O}_{3}$}

We use climatological ozone profiles from 23 ozonesonde stations averaged over July-August from 1985 to 2000, originally constructed by Considine et al. (2008) based on Logan (1999) and Thompson et al. (2003). The number of soundings at each station is adequate for defining monthly means used to evaluate the accuracy of the model results (Considine et al., 2008; Liu et al., 2016). 


\subsubsection{Satellite TOC}

Three TOC products are used in this study: Total Ozone Mapping Spectrometer (TOMS)-Solar Backscatter Ultraviolet (SBUV), OMI/MLS, and directly retrieved TOC from TES. The TOMS/SBUV TOC and OMI/MLS TOC are determined using the tropospheric ozone residual (TOR) method, which involves subtracting measurements of SBUV and MLS stratospheric column ozone (SCO) from TOMS and OMI total column ozone, respectively (Fishman et al., 2003; Ziemke et al., 2006). The TES TOCs are integrated from directly retrieved volume mixing ratios. We did not consider different instrument sensitivities because integrating retrievals significantly reduces the error due to averaging over pressure ranges larger than TES vertical resolution (Osterman et al., 2008; Zhang et al., 2012). The tropopause pressure is taken from the GEOS-4 meteorological data $\left(2^{\circ} \times 2.5^{\circ}\right)$. A description of TES retrievals is given in Sect. 2.2.3.

\subsection{3 $\mathrm{TES} \mathrm{O}_{3}$ and $\mathrm{CO}$}

The TES instrument on EOS-Aura routinely provides observations of tropospheric $\mathrm{O}_{3}$ and $\mathrm{CO}$ across the globe (Beer et al., 2001; Beer, 2006). The Aura satellite is on a polar sun-synchronous orbit with Equator crossing at 01:45 (descending) and 13:45 (ascending) local time. TES is a Fourier transform infrared emission spectrometer with high spectral resolution $\left(0.1 \mathrm{~cm}^{-1}\right)$ and wide spectral range $(650-$ $3050 \mathrm{~cm}^{-1}$ ) (Beer et al., 2001). The nadir footprint of TES is $5 \times 8 \mathrm{~km}$. TES observations consist of two modes: global survey and special observations (Beer et al., 2001). We use TES level 2, version 4 global survey nadir observations (http: //eosweb.larc.nasa.gov/), and only $\mathrm{O}_{3}$ and $\mathrm{CO}$ retrievals with the "Master" quality flag are used in this analysis. The retrievals of $\mathrm{O}_{3}$ have 1-1.5 degrees of freedom (DOF) in the profile at midlatitudes in summer, with peak sensitivities near 700 and $300-400 \mathrm{hPa}$, respectively (Parrington et al., 2008). TES CO profiles generally have $1-1.5$ DOF in the troposphere (Luo et al., 2007a, b). Detailed descriptions of the TES instrument and the $\mathrm{O}_{3}$ and $\mathrm{CO}$ retrieval algorithms are described in Beer et al. (2001), Worden et al. (2004), Bowman et al. (2002, 2006), and Beer (2006).

In this study, we use $\mathrm{O}_{3}$ and $\mathrm{CO}$ retrievals at the $618 \mathrm{hPa}$ level, where TES has good sensitivity for both $\mathrm{O}_{3}$ and $\mathrm{CO}$ centered in the MT, and excludes latitudes $>60^{\circ}$, where TES measurements are less reliable due to low brightness temperatures (Zhang et al., 2006). Due to limitation of TES vertical resolution (1-1.5 DOF in the troposphere for both $\mathrm{O}_{3}$ and $\mathrm{CO})$, TES averaging kernels are applied to the simulations to take into account the different sensitivities of the instruments. TES uses MOZART model output binned by month and in blocks of $10^{\circ}$ latitude by $60^{\circ}$ longitude as a priori profiles (Worden et al., 2004). Validation of TES $\mathrm{O}_{3}$ against ozonesondes showed that TES ozone typically has a high bias of about $10 \%$ in the UT (Worden et al., 2007) or 3-10 ppbv in the MT/UT (Nassar et al., 2008). TES CO has a negative bias $(<10 \%)$ compared to aircraft measurements in the $\mathrm{NH}$ midlatitude lower troposphere (LT)/MT during the INTEX-B mission (spring 2006) (Luo et al., 2007a).

\section{Model simulations of radionuclides, $\mathrm{O}_{3}$, and $\mathrm{CO}$}

\subsection{GMI simulations of radionuclides}

Figures 2 and 3 show the latitude-pressure cross sections of zonal mean concentrations of ${ }^{222} \mathrm{Rn}$ and stratospheric fraction (\%) of tropospheric ${ }^{7} \mathrm{Be}$ concentrations during JulyAugust for the values averaged over three meteorological data sets and the differences from the mean. Differences in zonal mean ${ }^{222} \mathrm{Rn}$ concentrations at $\mathrm{SH}$ midlatitudes among the three simulations are small despite much stronger shallow convection in fvGCM (Fig. 1). This reflects the fact that most convection at $\mathrm{SH}$ midlatitudes occurs over the ocean. However, GMI/fvGCM ${ }^{222} \mathrm{Rn}$ concentrations in the UT in the $\mathrm{NH}$ subtropics and at NH midlatitudes are $\sim 20-70 \%$ higher than those in other simulations due to the deeper convection in fvGCM (Fig. 1). In the tropical MT/UT, GMI/MERRA produced the lowest ${ }^{222} \mathrm{Rn}$ concentrations, consistent with the lower cutoff of convection in GMI/MERRA (Fig. 2). This is not inconsistent with the largest stratospheric influence in the tropical MT/UT in GMI/MERRA among the three meteorological data sets (Fig. 3). Previously, Junhua Liu et al. (2010) and Zhang et al. (2011) used GEOS-Chem simulations of $\mathrm{CO}$ and ${ }^{222} \mathrm{Rn}$ (driven by GEOS-4 DAS and GEOS-5 DAS meteorological data) to show that the tropical convection in GEOS-4 is deeper than in GEOS-5. Because the MERRA reanalysis utilizes the same GCM as the GEOS-5 DAS, it also utilizes the RAS convection.

The stratospheric contribution to the lower-tropospheric ${ }^{7} \mathrm{Be}$ concentrations in GMI/fvGCM peaks near 30 $75^{\circ} \mathrm{N}(20-25 \%)$, in contrast to the GMI/GEOS-4 and GMI/MERRA simulations (Fig. 3). The GMI/GEOS-4 and GMI/MERRA simulations show a similar pattern of stratospheric influence on the troposphere with maxima near 030 and $>30^{\circ} \mathrm{S}$ (20-30\%), respectively, in the LT. However, GMI/GEOS-4 suggests more stratospheric influence than GMI/MERRA in the MT near $30^{\circ} \mathrm{S}(30-35 \%)$ and near $30-45^{\circ} \mathrm{N}(\sim 25 \%)$. The stratospheric impacts on the tropical MT/UT are weakest in GMI/fvGCM and strongest in GMI/MERRA. At NH midlatitudes, stratospheric influences on the LT are largest and most extensive in GMI/fvGCM and smallest in GMI/MERRA. These differences in stratospheric influence that characterize these meteorological data sets will be used to interpret $\mathrm{GMI} \mathrm{O}_{3}$ and $\mathrm{CO}$ simulations driven by these meteorological fields (Sects. 3.2 and 4). 

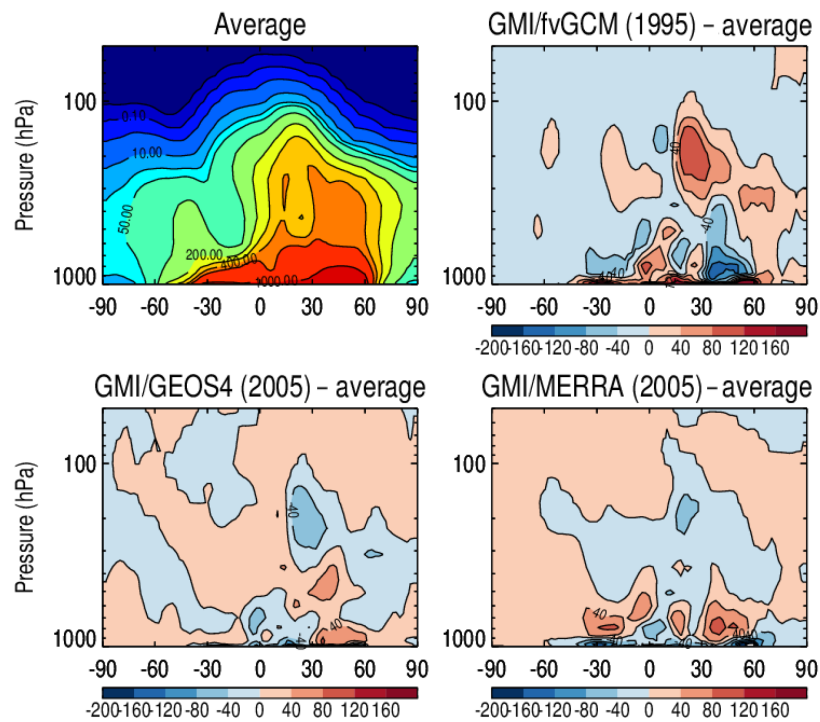

Figure 2. Latitude-pressure cross sections of zonal mean ${ }^{222} \mathrm{Rn}$ concentrations ( $\mathrm{mBq}$ per standard cubit meter (SCM)) as simulated by GMI for July-August. The plot shows the values averaged over three simulations driven by the fvGCM (1995), GEOS-4 (2005), and MERRA (2005) meteorological data sets, as well as differences of each simulation from the average.
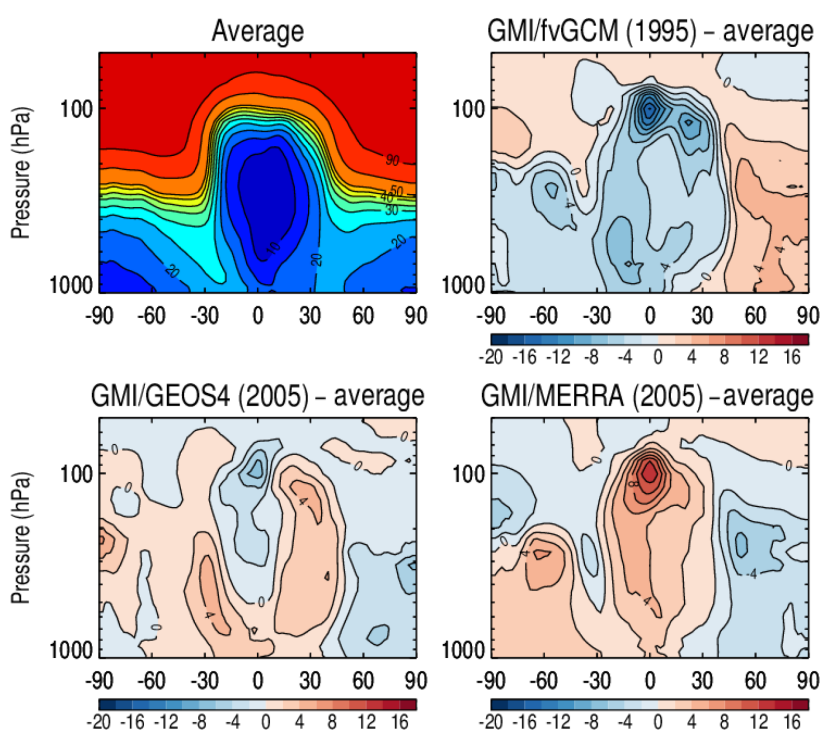

Figure 3. Same as Fig. 2 but for stratospheric fraction (\%) of zonal mean tropospheric ${ }^{7} \mathrm{Be}$ concentrations.

\subsection{GMI simulations of $\mathrm{O}_{3}$ and $\mathrm{CO}$}

Figures 4-5 show the latitude-pressure cross sections of zonal mean mixing ratios of $\mathrm{O}_{3}$ and $\mathrm{CO}$ during July-August averaged over three simulations and the differences from the mean. The latitudinal distributions of $\mathrm{O}_{3}$ from all simulations show the lowest $\mathrm{O}_{3}$ concentrations near the surface at high latitudes and in the tropical LT (Fig. 4). Relatively
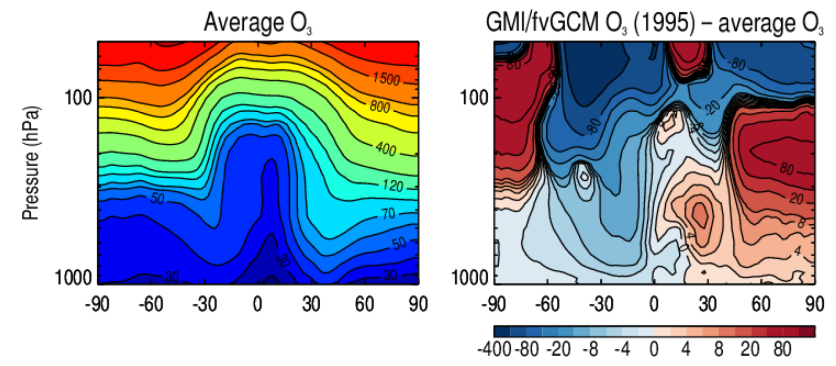

GMI/GEOS4 $\mathrm{O}_{3}(2005)$ - average $\mathrm{O}_{3}$

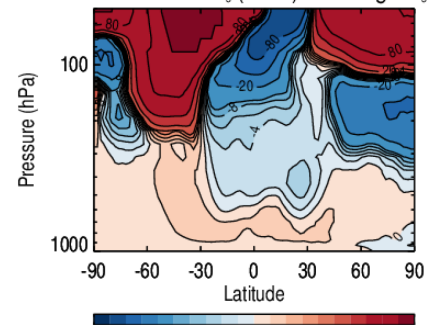

GMI/MERRA $\mathrm{O}_{3}(2005)$ - average $\mathrm{O}_{3}$

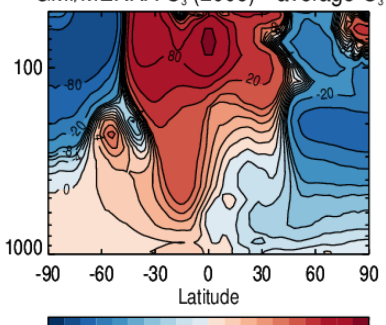

$-400-80-20 \begin{array}{cccccccc}-8 & -4 & 0 & 4 & 8 & 20 & 80\end{array}$

Figure 4. Same as Fig. 2 but for zonal mean ozone mixing ratios (ppbv).

low $\mathrm{O}_{3}$ in the tropical free troposphere results from transport of ozone-poor air from the LT to MT/UT via deep convection. High $\mathrm{O}_{3}$ concentrations are seen in the (subtropical) descending branches of the Hadley circulation partly due to the influence of STE. Compared with GMI/GEOS-4 and GMI/MERRA, GMI/fvGCM simulates higher $\mathrm{O}_{3}$ in the $\mathrm{NH}$ midlatitude MT and lower $\mathrm{O}_{3}$ in the SH LT/MT. This is likely due to higher STE in the NH and weaker STE in the $\mathrm{SH}$, respectively, as suggested by the higher (lower) fraction of stratospheric ${ }^{7} \mathrm{Be}$ seen in the GMI/fvGCM simulation than in the other two simulations (Fig. 3). On the other hand, GMI/MERRA simulates the highest $\mathrm{O}_{3}$ in the tropical MT/UT as a result of "stronger but shallower" deep convection in the tropics (Fig. 1). All simulations show the largest $\mathrm{CO}$ concentrations in the tropical LT/MT and NH midlatitude boundary layer (Fig. 5). The former reflects convective lifting of tropical biomass burning $\mathrm{CO}$ emissions, and the latter anthropogenic $\mathrm{CO}$ emissions. Among the three simulations, GMI/fvGCM simulates the lowest $\mathrm{CO}$ concentrations in the tropical MT/UT as well as both hemispheres. In the $\mathrm{NH}$ MT/UT in GMI/fvGCM, the low CO concentrations result from high $\mathrm{OH}$ concentrations associated with high $\mathrm{O}_{3}$ concentrations due to higher STE, which will be discussed in Sect. 4.1. In the SH GMI/fvGCM, the low CO concentrations are due to high $\mathrm{OH}$ concentrations as a result of toolow $\mathrm{NO}_{x}$ emissions from lightning (see Sect. 4.1). Tropical MT/UT CO concentrations in GMI/MERRA are not as high as those in GMI/GEOS-4, again reflecting the "shallower" tropical deep convection in MERRA. 

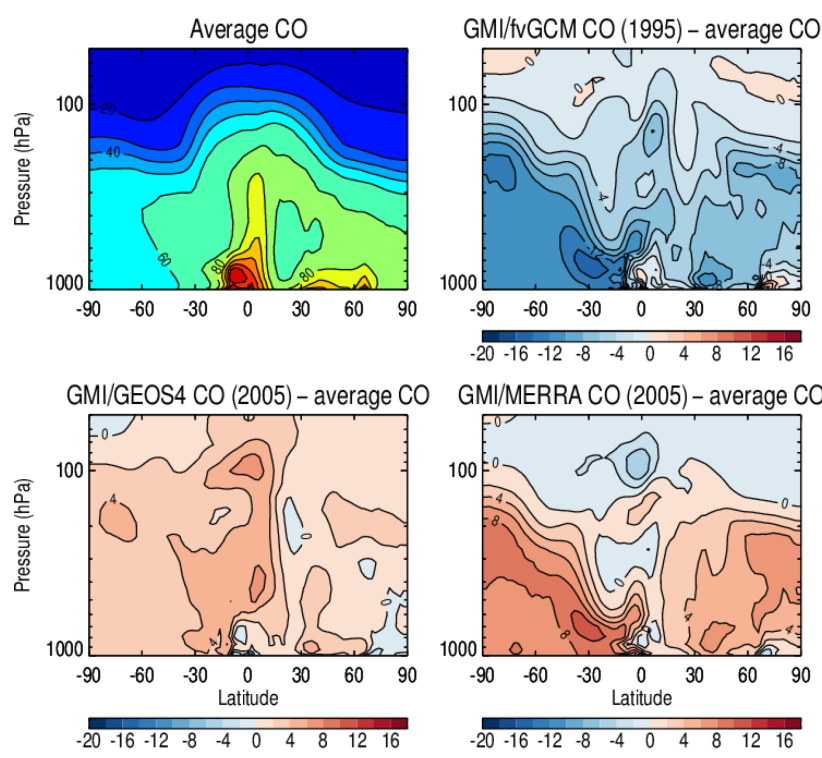

Figure 5. Same as Fig. 2 but for zonal mean $\mathrm{CO}$ mixing ratios (ppbv).

\section{Evaluation of GMI $\mathrm{O}_{3}$ and $\mathrm{CO}$ simulations with observations}

In this section, we evaluate $\mathrm{GMI} \mathrm{O}_{3}$ and $\mathrm{CO}$ simulations driven by the fvGCM, GEOS-4, and MERRA meteorological data sets with ozonesonde $\mathrm{O}_{3}$ vertical profiles, satellite TOC, and TES $\mathrm{O}_{3}$ and $\mathrm{CO}$ retrievals.

\subsection{Ozone vertical profiles and tropospheric ozone column}

Figure 6 compares GMI-simulated tropospheric $\mathrm{O}_{3}$ profiles with ozonesonde observations averaged over July-August for a range of latitudes. These results are typical of other stations at similar latitudes. The mean differences between simulated $\mathrm{O}_{3}$ and ozonesonde observations at $500 \mathrm{hPa}(\mathrm{MT})$ and $200 \mathrm{hPa}$ (UT) are listed in Table 2. GMI/fvGCM overestimates $\mathrm{O}_{3}$ in the NH mid- and high-latitude MT/UT (e.g., Churchill, Hohenpeissenberg, and Sapporo). This may be due to excessive STE given the relatively high fractions of ${ }^{7} \mathrm{Be}$ from the stratosphere (Fig. 3). The overestimate may also be partly attributed to strong convective mass fluxes at $\mathrm{NH}$ midlatitudes that lift more $\mathrm{O}_{3}$ and/or its precursors from the surface (Figs. 1-2). Figure 6 also shows that GMI/fvGCM underestimates $\mathrm{O}_{3}$ in the $\mathrm{SH}$ (e.g., Reunion Island). Since stratospheric ${ }^{7} \mathrm{Be}$ fractions are relatively low in this simulation, the $\mathrm{O}_{3}$ underestimate may be due to overly weak STE (cf. Fig. 3). Low emissions of lightning $\mathrm{NO}_{x}$, an important precursor of tropospheric $\mathrm{O}_{3}$, could also play a role. It is noted that all simulations show hot spots of $\mathrm{LNO}_{x}$ emissions over the central and eastern US, central Africa, and the west Tibetan Plateau (not shown). Lightning $\mathrm{NO}_{x}$ emissions between 10 and $70^{\circ} \mathrm{S}$ in $\mathrm{GMI} / \mathrm{fvGCM}$
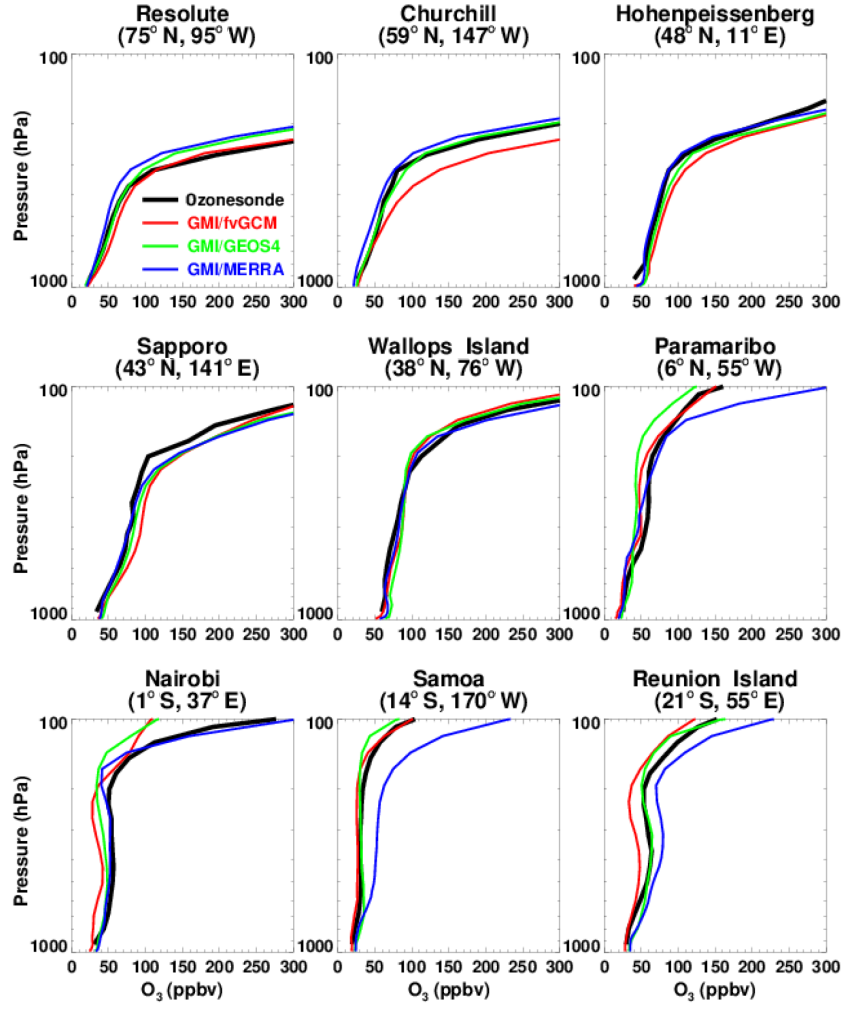

Figure 6. Comparisons of GMI-simulated tropospheric ozone profiles (color lines) with ozonesonde observations (black line) for a range of latitudes. The model is driven by the fvGCM, GEOS-4, and MERRA meteorological fields. Values are July-August average.

during July-August are similar to those in GMI/GEOS-4 and GMI/MERRA, but the emissions during May-June are a factor of $\sim 2.5$ lower than those in GMI/GEOS-4 and GMI/MERRA (Table 1). Since $\mathrm{O}_{3}$ has a lifetime of weeks to months in the MT/UT, a low- $\mathrm{O}_{3}$ bias during May-June will lead to lower $\mathrm{O}_{3}$ during July-August in GMI/fvGCM. GMI/GEOS-4 simulates $\mathrm{O}_{3}$ in both hemispheres reasonably well but underestimates $\mathrm{O}_{3}$ in the tropical MT/UT, as seen at Paramaribo and Nairobi in Fig. 6. GMI/MERRA underestimates $\mathrm{O}_{3}$ in the NH high-latitude UT (e.g., Resolute) likely due to weak STE compared to GMI/GEOS-4 as suggested by ${ }^{7} \mathrm{Be}$ tracer simulations (Fig. 3), while it overestimates $\mathrm{O}_{3}$ with a high bias in the SH subtropics (e.g., Samoa and Reunion Island) because of a combination of excessive influences from lightning $\mathrm{NO}_{x}$ emissions in May (Table 1) and STE (or subsidence from the UT) (Fig. 3). In addition, the shallower tropical convection (Fig. 1) accompanied by larger STE contribution in the southern tropical MT/UT (Fig. 3) results in less clean air being lifted from the LT to MT/UT.

Figure 7 shows GMI-simulated zonal mean TOCs averaged over July-August in comparison with TORs determined from TOMS/SBUV (Fishman et al., 2003), OMI/MLS (Ziemke et al., 2006), and TOCs directly retrieved from 
Table 1. Global lightning $\mathrm{NO}_{x}$ emissions $\left(\mathrm{Tg} \mathrm{N} \mathrm{mon}^{-1}\right)$ during May-August in the GMI CTM driven by three meteorological data sets (fvGCM, GEOS-4, and MERRA).

\begin{tabular}{lrrrr}
\hline & May & Jun & Jul & Aug \\
\hline fvGCM & $0.57\left(0.03^{*}\right)$ & $0.65(0.02)$ & $0.80(0.03)$ & $0.78(0.05)$ \\
GEOS-4 & $0.64(0.05)$ & $0.73(0.07)$ & $0.82(0.03)$ & $0.72(0.05)$ \\
MERRA & $0.49(0.07)$ & $0.69(0.07)$ & $0.81(0.03)$ & $0.78(0.04)$ \\
\hline
\end{tabular}

* Values in parentheses denote lightning $\mathrm{NO}_{x}$ emissions between 10 and $70^{\circ} \mathrm{S}$.

Table 2. Mean differences (ppbv) between GMI-simulated $\mathrm{O}_{3}$ and ozonesonde observations at 500 and $200 \mathrm{hPa}$.

\begin{tabular}{lrr|rr|rr}
\hline Ozonesonde station & \multicolumn{2}{c|}{ GMI/fvGCM-sonde } & \multicolumn{2}{c}{ GMI/GEOS-4-sonde } & \multicolumn{2}{c}{ GMI/MERRA-sonde } \\
\cline { 2 - 6 } & $500 \mathrm{hPa}$ & $200 \mathrm{hPa}$ & $500 \mathrm{hPa}$ & $200 \mathrm{hPa}$ & $500 \mathrm{hPa}$ & $200 \mathrm{hPa}$ \\
\hline Resolute $\left(75^{\circ} \mathrm{N}, 95^{\circ} \mathrm{W}\right)$ & 8.53 & 48.37 & 1.72 & -65.79 & -7.33 & -85.56 \\
Churchill $\left(59^{\circ} \mathrm{N}, 147^{\circ} \mathrm{W}\right)$ & 10.52 & 129.41 & -0.30 & -8.82 & -8.98 & -38.87 \\
Hohenpeissenberg $\left(48^{\circ} \mathrm{N}, 11^{\circ} \mathrm{E}\right)$ & 9.53 & 43.85 & 4.81 & 33.60 & -3.15 & 2.20 \\
Sapporo $\left(43^{\circ} \mathrm{N}, 141^{\circ} \mathrm{E}\right)$ & 14.07 & 41.76 & 5.58 & 39.03 & -2.95 & 34.90 \\
Wallops Island $\left(38^{\circ} \mathrm{N}, 76^{\circ} \mathrm{W}\right)$ & 9.21 & -11.07 & 13.14 & -14.83 & 6.41 & -6.91 \\
Paramaribo $\left(6^{\circ} \mathrm{N}, 55^{\circ} \mathrm{W}\right)$ & -9.46 & -8.11 & -10.74 & -19.83 & -12.84 & 7.38 \\
Nairobi $\left(1^{\circ} \mathrm{S}, 37^{\circ} \mathrm{E}\right)$ & -10.94 & -15.53 & -4.35 & -15.91 & -1.62 & -8.20 \\
Samoa $\left(14^{\circ} \mathrm{S}, 170^{\circ} \mathrm{W}\right)$ & -5.33 & -7.27 & -2.45 & -4.01 & 17.22 & 27.85 \\
Reunion Island $\left(21^{\circ} \mathrm{S}, 55^{\circ} \mathrm{E}\right)$ & -11.49 & -17.30 & 0.51 & -2.50 & 8.38 & 16.91 \\
\hline
\end{tabular}

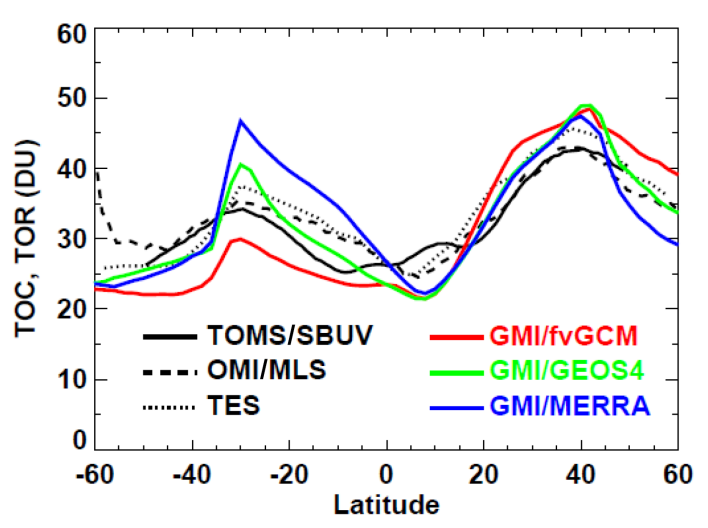

Figure 7. GMI-simulated zonal mean tropospheric ozone columns (TOCs) compared with tropospheric ozone residuals (TORs) determined from TOMS/SBUV (July-August 19792005 multi-year average; Fishman et al., 2003) and OMI/MLS (July-August 2005 average; Ziemke et al., 2006), and TOCs determined from TES retrievals (July-August 2005 average).

TES measurements. The World Meteorological Organization (WMO) definition of thermal tropopause is used to calculate the model TOC, following Liu et al. (2016). The latitudinal distribution of TOCs shows a trough in the tropics and polar regions, and a peak at midlatitudes in both the models and the observations. The TORs determined from TOMS/SBUV and OMI/MLS agree well with each other in the NH, but those from OMI/MLS are lower at $\sim 10^{\circ} \mathrm{N}$ and higher south of $50^{\circ} \mathrm{S}$. The TOCs determined from TES are more similar to the OMI/MLS TORs, albeit biased high in the northern subtropics and biased low south of $40^{\circ} \mathrm{S}$. A comparison of Fig. 7 with 6 indicates that the TOCs from three model simulations coincide with the above results from model evaluations with ozonesonde $\mathrm{O}_{3}$ profiles. For example, both evaluations suggest negative biases in the $\mathrm{SH}$ and positive biases at $\mathrm{NH}$ midand high latitudes in GMI/fvGCM, and positive biases in the southern subtropics in GMI/MERRA.

\section{$4.2 \mathrm{O}_{3}$ and $\mathrm{CO}$ concentrations at $618 \mathrm{hPa}$}

Figure 8 shows the July-August mean concentrations of $\mathrm{O}_{3}$ and $\mathrm{CO}$ at $618 \mathrm{hPa}$ in the GMI simulations. Figure 9 shows the corresponding global distributions of ${ }^{222} \mathrm{Rn}$ concentrations, stratospheric fractions (\%) of mean tropospheric ${ }^{7} \mathrm{Be}$ concentrations, and ratios ${ }^{7} \mathrm{Be} /{ }^{210} \mathrm{~Pb}$. All simulations show the highest $\mathrm{O}_{3}$ concentrations at $\mathrm{NH}$ midlatitudes and the lowest $\mathrm{O}_{3}$ concentrations in the tropical western Pacific. They also simulate a narrow band of relatively high $\mathrm{O}_{3}$ concentrations in the southern tropics and subtropics. GMI/fvGCM simulates the highest $\mathrm{O}_{3}$ concentrations at $\mathrm{NH}$ mid- and high latitudes (Fig. 8, left panel) likely due to STE, as indicated by a large fraction of ${ }^{7} \mathrm{Be}$ transported down from the stratosphere (Fig. 9, middle top panel). By contrast, it simulates the lowest $\mathrm{O}_{3}$ concentrations in the southern tropics and subtropics, especially over southern Africa and the South Atlantic Ocean. In this region, GMI/MERRA simulates the highest $\mathrm{O}_{3}$ concentrations attributed to high lightning $\mathrm{NO}_{x}$ emissions (Table 1), large STE (Fig. 9, middle bottom panel), and biomass burning emissions lifted by shal- 

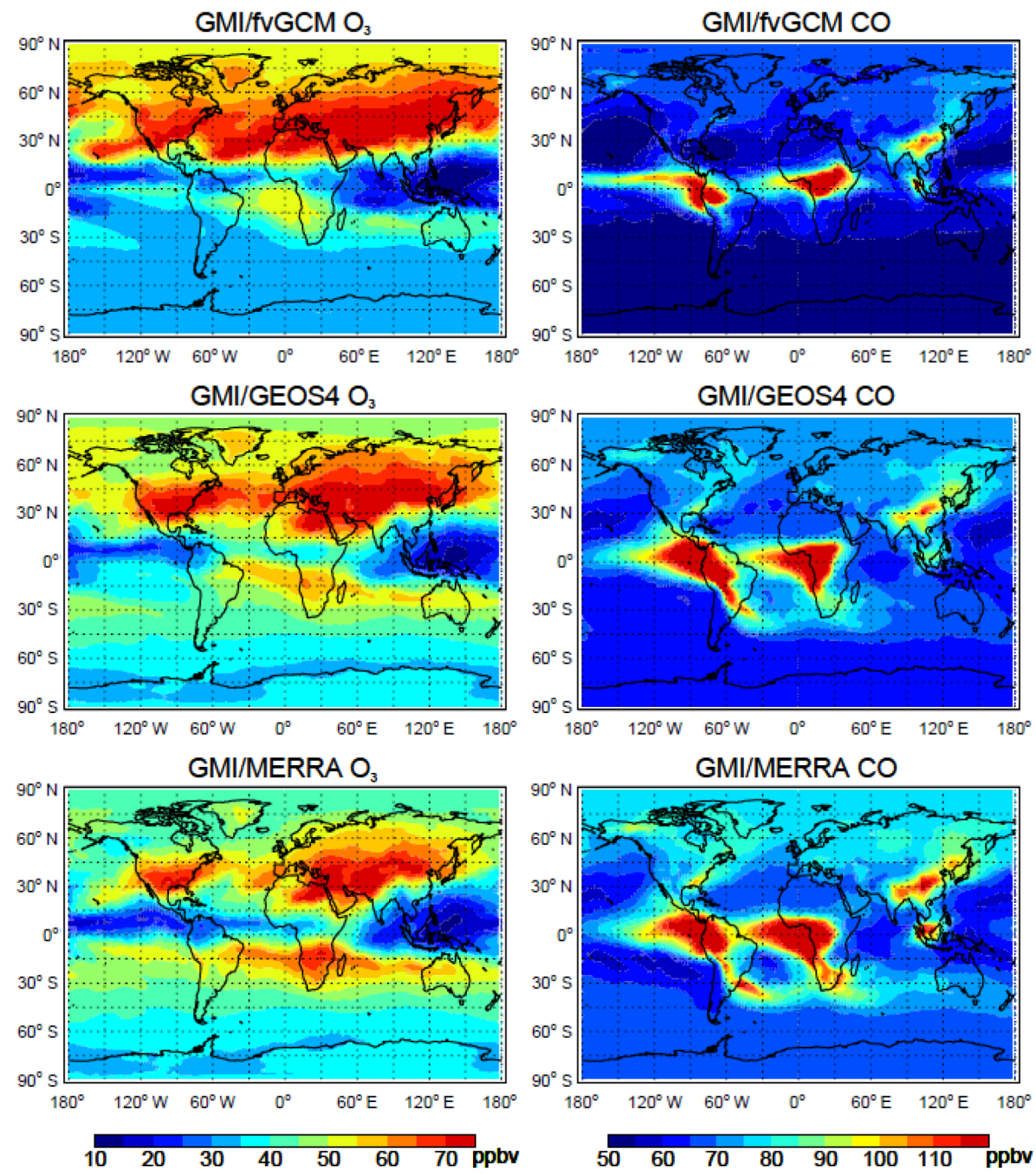

Figure 8. July-August mean mixing ratios of $\mathrm{O}_{3}$ and $\mathrm{CO}$ (ppbv) at $618 \mathrm{hPa}$ as simulated by the GMI CTM driven by three meteorological data sets (1995 for fvGCM, 2005 for GEOS-4 and MERRA).

low but strong convection (Sect. 3; Fig. 9, left bottom panel). Thompson et al. (1996) previously suggested that the $\mathrm{O}_{3}$ maximum observed in southern Africa and the adjacent Atlantic during September-October 1992 is caused by the coincidence of $\mathrm{O}_{3}$ precursors from biomass burning with long residence time, and deep convection with additional lightning $\mathrm{NO}_{x}$ and biogenic sources. As we will show in Sect. 5, the emission types contributing to the $\mathrm{O}_{3}$ enhancements over this region in July-August mainly include lightning $\mathrm{NO}_{x}$ and, to a lesser extent, biomass burning.

All simulations show a similar pattern of $\mathrm{CO}$ concentrations at $618 \mathrm{hPa}$, e.g., $\mathrm{CO}$ enhancements due to biomass burning emissions lifted by convection (e.g., South America, Africa, Indonesia, and Alaska) and anthropogenic emissions (e.g., East Asia, South Asia, and eastern North America) (Fig. 8, right column). This pattern also reflects the geographic distribution of these emissions. GMI/fvGCM sim- ulates the lowest $\mathrm{CO}$ concentrations at $618 \mathrm{hPa}$ in most of the polluted regions due to stronger STE of $\mathrm{O}_{3}$, as discussed in Sect. 4.1. GMI/GEOS-4 simulates slightly lower CO concentrations in East and South Asia and its outflow region, North America and its outflow region, and Indonesia than GMI/MERRA does. GMI/GEOS-4 also simulates lower CO concentrations over subtropical South American and southern African westerly outflow regions.

To evaluate $\mathrm{GMI} \mathrm{O}_{3}$ and $\mathrm{CO}$ simulations with satellite observations, we use TES retrievals at $618 \mathrm{hPa}$, where TES has good sensitivity for both $\mathrm{O}_{3}$ and $\mathrm{CO}$ in the MT (Zhang et al., 2006). GMI model output was sampled along the TES orbit track at the observation time and then interpolated onto the 67 vertical pressure levels of TES retrievals. Since the model output was saved every $3 \mathrm{~h}$, the temporal offset with TES is up to $1.5 \mathrm{~h}$. To compare the model output with the TESretrieved profiles, TES averaging kernels and a priori were 

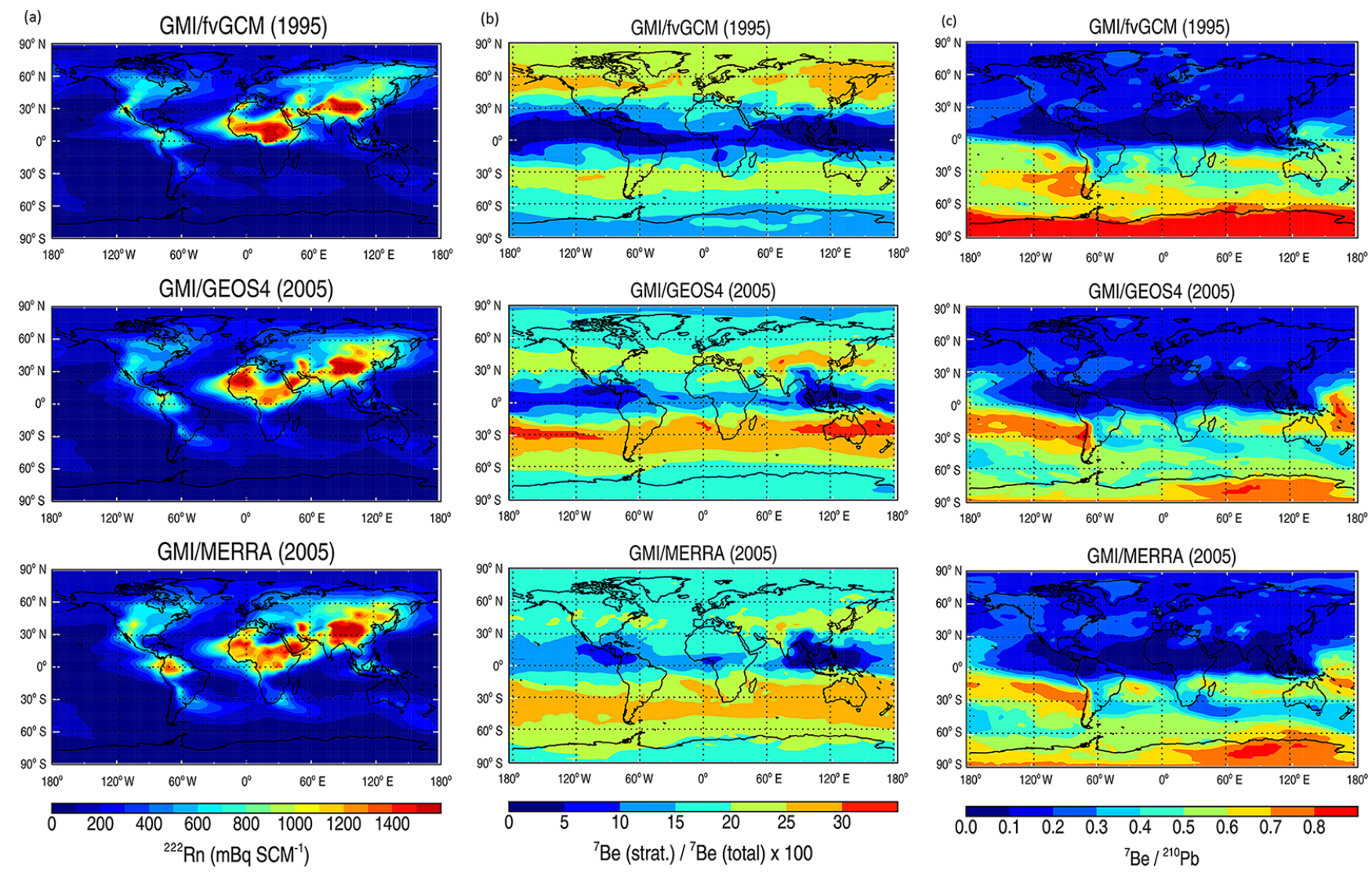

Figure 9. Mean ${ }^{222} \mathrm{Rn}$ concentrations $\left(\mathrm{mBq} \mathrm{SCM}^{-1}\right)$ (a), stratospheric fraction (\%) of tropospheric ${ }^{7}$ Be concentrations $(\mathbf{b})$, and ratios of ${ }^{7} \mathrm{Be}$ to ${ }^{210} \mathrm{~Pb}$ volume mixing ratios (c) at $618 \mathrm{hPa}$ in the GMI model driven by the fvGCM (1995), GEOS-4 (2005), and MERRA (2005) meteorological data sets for the period of July-August.

applied to the model output. Both the model output and TES data were gridded onto grids of $10^{\circ}$ latitude by $10^{\circ}$ longitude by averaging all values within each grid box. Figures 10-11 show the mean concentrations of $\mathrm{O}_{3}$ and $\mathrm{CO}$ at $618 \mathrm{hPa}$ observed by TES during July-August 2005 and corresponding GMI CTM results.

TES observed enhanced $\mathrm{O}_{3}$ concentrations over the Middle East, northern Africa, southern Africa, North America, and East Asia (Fig. 10). Increased levels of $\mathrm{O}_{3}$ were also observed in continental outflow regions, especially the western North Pacific, North Atlantic, tropical South Atlantic, and southern subtropical Indian Ocean. All simulations capture the spatial distributions of $\mathrm{O}_{3}$ well but underestimate the enhancements over southern Africa and adjacent oceans. GMI/fvGCM simulates reasonably well the TESobserved $\mathrm{O}_{3}$ enhancements at $\mathrm{NH}$ mid- and high latitudes but slightly underestimates the low $\mathrm{O}_{3}$ concentrations in the tropical western Pacific and Indian Ocean. GMI/GEOS-4 and GMI/MERRA simulations show lower $\mathrm{O}_{3}$ concentrations at NH mid- and high latitudes than TES observations. However, considering that TES $\mathrm{O}_{3}$ has a positive bias of 3-10 ppbv in the MT (Nassar et al., 2008), GMI/fvGCM may very well overestimate $\mathrm{O}_{3}$ at $\mathrm{NH}$ midlatitudes, while GMI/GEOS-4 and GMI/MERRA simulations are closer to reality. This conclusion is consistent with that from the comparison of GMI simulations with ozonesonde observations (Fig. 6).

Enhanced $\mathrm{CO}$ concentrations were observed by TES over Africa, South America, North America, and Eurasia (Fig. 11). All simulations underestimated $\mathrm{CO}$ concentrations in most of those CO hot spots in the NH. GMI/GEOS-4 captured fairly well high $\mathrm{CO}$ concentrations over biomass burning regions in South America and southern Africa. However, considering TES CO biases, i.e., a negative bias at NH midlatitudes and a positive bias in the tropics (Luo et al., 2007a; Lopez et al., 2008), all simulations significantly underestimate $\mathrm{CO}$ enhancements at $\mathrm{NH}$ midlatitudes but simulate better $\mathrm{CO}$ enhancements over the tropical biomass burning regions. This is consistent with a previous study by Shindell et al. (2006), who found a multi-model underestimate of $\mathrm{NH}$ extratropical CO likely due to current inventories underestimating fossil fuel emissions in East Asia and biomass burning emissions in south-central Africa. 

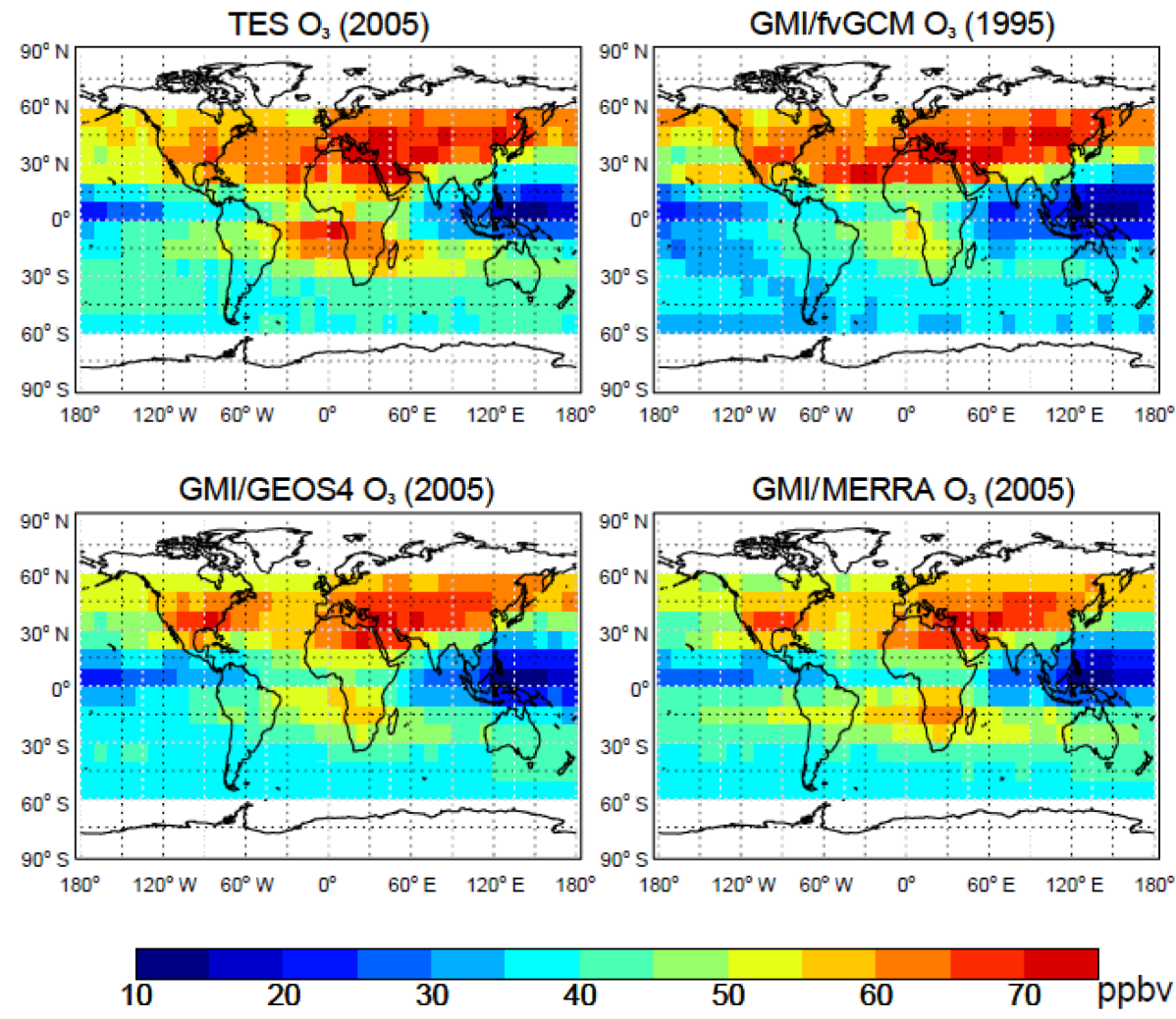

Figure 10. Mean mixing ratios of $\mathrm{O}_{3}$ at $618 \mathrm{hPa}$ observed by TES during July-August 2005 and corresponding GMI CTM results with 3hourly output sampled along the TES orbit tracks. TES averaging kernels and a priori were applied to the model output. Results are averaged into $10^{\circ} \times 10^{\circ}$ grid cells.

\section{$5 \mathrm{O}_{3}$ and $\mathrm{CO}$ relationships}

In this section, we examine $\mathrm{O}_{3}$ and $\mathrm{CO}$ relationships at $618 \mathrm{hPa}$ in the GMI CTM. We interpret GMI-simulated $\mathrm{O}_{3}-$ $\mathrm{CO}$ correlations and their slopes in the context of emissions, photochemical transformation, and transport (e.g., convection, STE, and large-scale subsidence), using model meteorological data and radionuclide simulations. We then evaluate them with those derived from TES satellite observations. Note that the model underestimate of $\mathrm{CO}$ concentrations does not significantly affect the calculated $\mathrm{O}_{3}-\mathrm{CO}$ correlations, although it may cause biases in the regression slopes due to the association of the latter with ozone production efficiency.

\subsection{GMI O $\mathrm{O}_{3}-\mathrm{CO}$ correlations}

Figure 12 shows the $\mathrm{O}_{3}-\mathrm{CO}$ correlation coefficients $(R)$ and linear regression slopes $\left(\mathrm{dO}_{3} / \mathrm{dCO}\right)$ at $618 \mathrm{hPa}$ for JulyAugust, as calculated using the reduced major-axis method with 3-hourly output from the GMI/fvGCM, GMI/GEOS-4, and GMI/MERRA simulations. We discuss the common features in the correlation patterns in all simulations, followed by their discrepancies. All simulations show strong positive $\mathrm{O}_{3}-\mathrm{CO}$ correlations and large $\mathrm{dO}_{3} / \mathrm{dCO}$ enhancement ratios in the NH major continental outflow regions, e.g., At- lantic Seaboard, North Atlantic, and North Pacific, consistent with previous modeling studies (Zhang et al., 2006; Voulgarakis et al., 2011) and in situ observations (e.g., Anderson et al. 1993; Chin et al., 1994; Jaffe et al., 1996; Parrish et al., 1998; Tsutsumi and Matsueda, 2000; Mao and Talbot, 2004). Our simulations also suggest a much larger area with high correlations that extends from the western to eastern North Pacific. We found that strong positive correlation regions are not co-located with maximum $\mathrm{O}_{3}$ and $\mathrm{CO}$ concentrations in all simulations. Instead, they are located between most polluted and clean areas, reflecting the intrusion of high- $\mathrm{O}_{3}$ (and high-CO) air from midlatitudes and low- $\mathrm{O}_{3}$ (and low-CO) air from the tropics. Fishman and Seiler (1983) and Mauzerall et al. (2000) previously suggested that strong positive $\mathrm{O}_{3}-\mathrm{CO}$ correlations in low-CO regions may be caused by the depletion of both $\mathrm{O}_{3}$ and $\mathrm{CO}$ in tropical air.

All simulations show positive $\mathrm{O}_{3}-\mathrm{CO}$ correlations in the SH marine regions, but GMI/MERRA simulates much stronger negative correlations over the equatorial Atlantic. The latter reflects the stronger convection in the LT/MT in MERRA, which will be discussed below. Positive $\mathrm{O}_{3}-\mathrm{CO}$ correlations were previously observed over the tropical South Atlantic during the TRACE-A aircraft mission (SeptemberOctober, 1992) (e.g., Collins Jr. et al., 1996). Collins et 

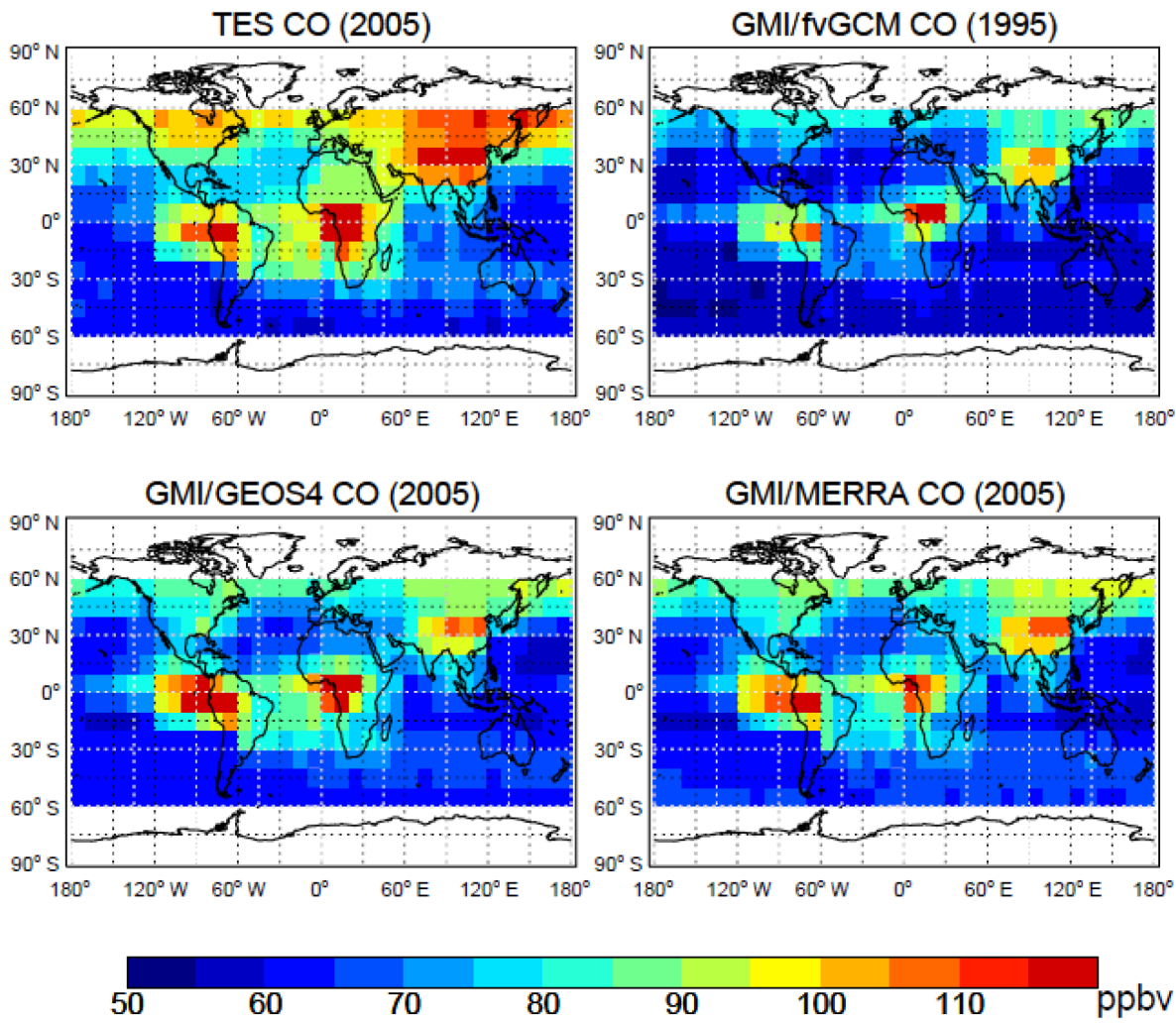

Figure 11. Same as Fig. 10 but for CO.

al. concluded that the $\mathrm{O}_{3}-\mathrm{CO}$ correlations over the tropical South Atlantic are more affected by in situ photochemical production from aged biomass burning plumes (positive $\mathrm{O}_{3}-$ $\mathrm{CO}$ correlation) than transport from the stratosphere (negative $\mathrm{O}_{3}-\mathrm{CO}$ and $\mathrm{O}_{3}$-dew point correlations).

Strong positive $\mathrm{O}_{3}-\mathrm{CO}$ correlations are present in all simulations at $618 \mathrm{hPa}$ over western and central Indonesia (Fig. 12), reflecting convective transport of biomass burning $\mathrm{CO}$ (Fig. 8) and photochemical production of $\mathrm{O}_{3}$ from its precursors. The $\mathrm{dO}_{3} / \mathrm{dCO}$ enhancement ratios over Indonesia are not as large as those over the NH midlatitude continental outflow regions due to the fact that biomass burning emits $\mathrm{NO}_{x}$ less efficiently than fossil fuel does.

Positive $\mathrm{O}_{3}-\mathrm{CO}$ correlations over the westerly African biomass burning outflow region (southern Indian Ocean, $\sim 45^{\circ} \mathrm{S}$ ) are seen in all simulations (Fig. 12). The positive $\mathrm{O}_{3}-\mathrm{CO}$ correlations over both the NH midlatitude continental outflow regions and the westerly African biomass burning outflow regions mainly reflect $\mathrm{O}_{3}$ and $\mathrm{CO}$ signatures from different sources: (1) anthropogenic emissions of $\mathrm{CO}$ and other $\mathrm{O}_{3}$ precursors in the former and biomass burning emissions in the latter (Fig. 8), and (2) significant influences from the stratosphere and subsidence from the UT/LS (Fig. 9, middle and right columns, respectively). In the case of (1), the $\mathrm{dO}_{3} / \mathrm{dCO}$ slopes in the westerly African biomass burning outflow are smaller than those in the $\mathrm{NH}$ midlatitude continental outflow, again reflecting the lower efficiency of biomass burning $\mathrm{NO}_{x}$ emissions than that of fossil fuel $\mathrm{NO}_{x}$ emissions. In the case of (2), mixing of stratospheric air (high $\mathrm{O}_{3}$ ) with polluted air masses (high $\mathrm{CO}$ ) has previously been found associated with positive $\mathrm{O}_{3}-\mathrm{CO}$ correlations downwind from outflow regions (Cooper et al., 2002; Kim et al., 2013).

Strong negative $\mathrm{O}_{3}-\mathrm{CO}$ correlations are seen in all simulations over the tropical eastern North Pacific, the Caribbean, the tropical North Atlantic, and equatorial Africa. These negative correlations are primarily a result of convective transport of low- $\mathrm{O}_{3}$ air masses impacted by biogenic emissions. As will be discussed in Section 6, significant decreases in $\mathrm{O}_{3}$ and increases in $\mathrm{CO}$ occur near the above regions due to atmospheric oxidation of biogenic VOCs (e.g., isoprene) over tropical America and Africa. In addition, our results show weak positive (in GMI/fvGCM and GMI/GEOS-4) or strong negative (in GMI/MERRA) $\mathrm{O}_{3}-\mathrm{CO}$ correlations over much of the southern tropics and subtropics, especially near the biomass burning outflow regions. Negative $\mathrm{O}_{3}-\mathrm{CO}$ correlations in the southern tropics during July-August were previously reported by Fishman and Seiler (1983). Based on aircraft measurements, they concluded that $\mathrm{O}_{3}$ destruction in the southern tropical LT, where the major CO sources (biomass burning emissions) are located, may lead to strong negative correlations (see their Fig. 3). 

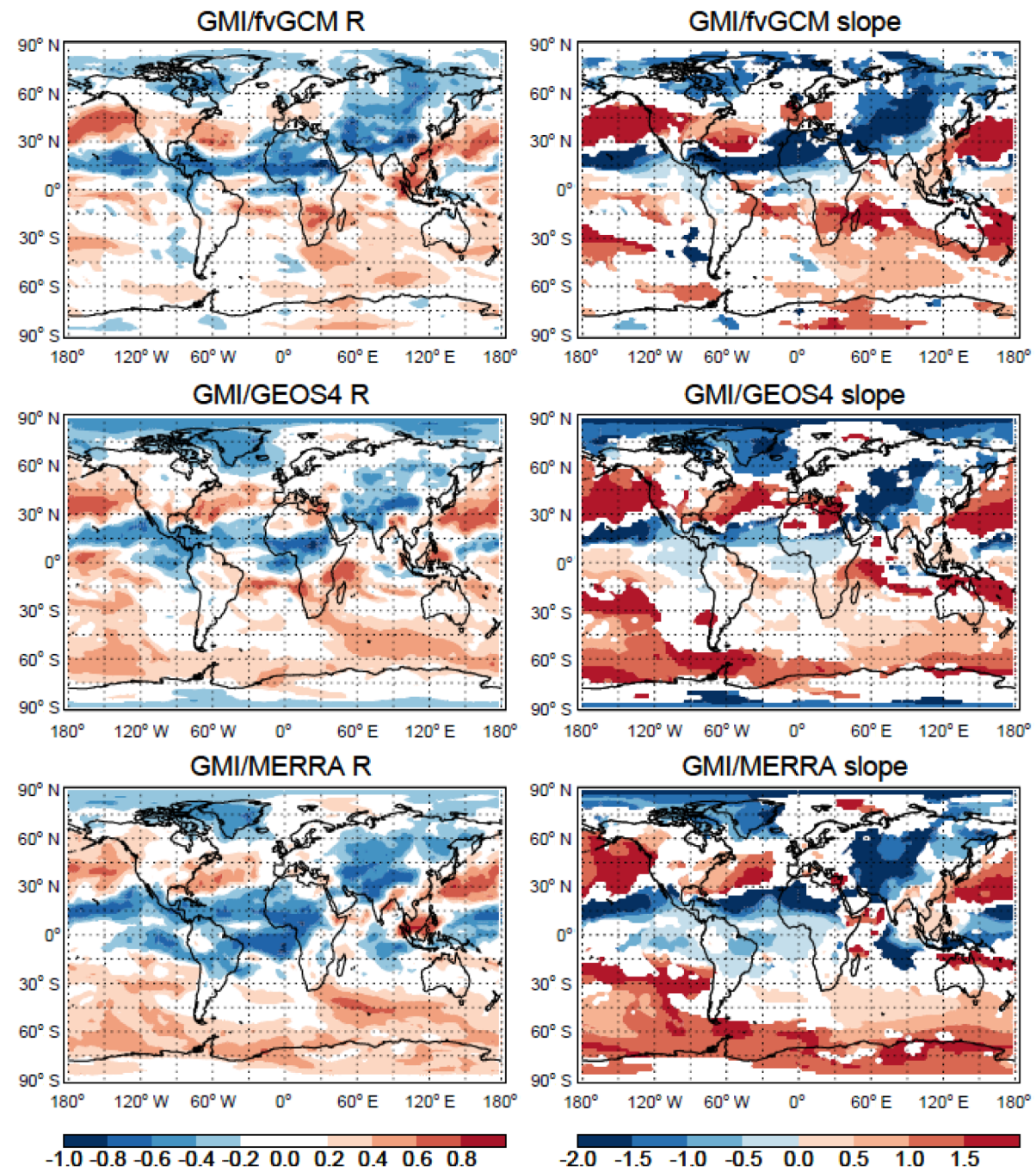

Figure 12. $\mathrm{O}_{3}-\mathrm{CO}$ correlation coefficients $(R)$ and linear regression slopes $\left(\mathrm{dO}_{3} / \mathrm{dCO}\right)$ at $618 \mathrm{hPa}$ in the GMI model driven by the fvGCM (1995), GEOS-4 (2005), and MERRA (2005) meteorological fields. Results are calculated in $2^{\circ} \times 2.5^{\circ}$ grid cells using 3-hourly model output and the reduced major-axis method. White areas denote absolute values of $\mathrm{O}_{3}-\mathrm{CO}$ correlation coefficients less than 0.2 .

All GMI simulations show strong negative $\mathrm{O}_{3}-\mathrm{CO}$ correlations over the Asian continent, including the Middle East (Fig. 12). Over southwestern China (e.g., Sichuan Basin), monsoonal convective lifting of air masses with high $\mathrm{CO}$ and low $\mathrm{O}_{3}$ leads to negative $\mathrm{O}_{3}-\mathrm{CO}$ correlations. For most other regions, high $\mathrm{O}_{3}$ and low $\mathrm{CO}$ associated with stratospherically influenced air (Fig. 9, middle column) result in negative $\mathrm{O}_{3}-\mathrm{CO}$ correlations with large (negative) $\mathrm{dO}_{3} / \mathrm{dCO}$ ratios. As will be discussed in Sect. 6, lightning $\mathrm{NO}_{x}$ emissions also contribute to these negative correlations over the Asian continent. Our simulations over the Tibetan Plateau are consistent with the study of Wang et al. (2006), who inferred negative $\mathrm{O}_{3}-\mathrm{CO}$ correlations from in situ measurements at Mount Waliguan, located at the northeastern edge of the Tibetan Plateau during summer due to downward transport from the UT/LS.
While the $\mathrm{O}_{3}-\mathrm{CO}$ correlations in the three simulations show similarities, they also show differences. The global $\mathrm{O}_{3}-$ $\mathrm{CO}$ correlation patterns in GMI/fvGCM and GMI/GEOS-4 are more similar, presumably because fvGCM is the GCM in the GEOS-4 assimilation, and they use the same convection scheme. Even so, significantly different $\mathrm{O}_{3}-\mathrm{CO}$ correlation coefficients between GMI/fvGCM and GMI/GEOS4 are seen in northern Africa, where the former simulates strong negative but the latter shows weak positive correlations. As indicated by radionuclide tracers $\left({ }^{210} \mathrm{~Pb}\right.$ and $\left.{ }^{7} \mathrm{Be}\right)$, fvGCM has relatively stronger large-scale subsidence over northern Africa at $618 \mathrm{hPa}$ than GEOS-4, resulting in strong correlations with a large negative slope. In addition, the $\mathrm{O}_{3}-\mathrm{CO}$ correlations in GMI/MERRA are strongly negative over northern South America, the tropical western South Atlantic Ocean, the Indian Ocean, and the tropical western Pa- 

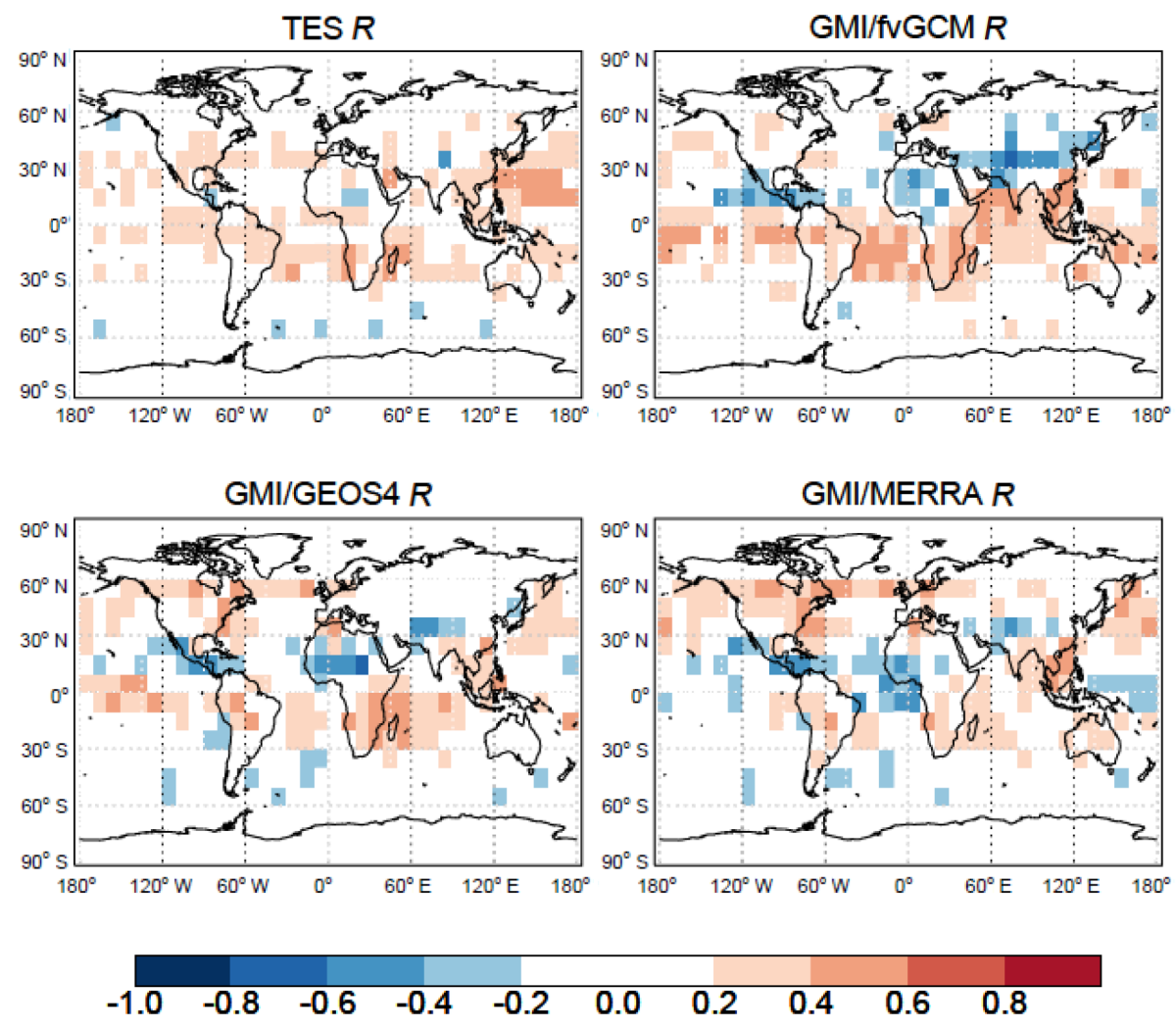

Figure 13. $\mathrm{O}_{3}-\mathrm{CO}$ correlation coefficients $(R)$ at $618 \mathrm{hPa}$ as determined by $\mathrm{O}_{3}$ and $\mathrm{CO}$ observations from TES during July-August 2005, and corresponding GMI CTM results with 3-hourly output sampled along the TES orbit tracks. TES averaging kernels, spectral errors, and a priori are applied. Results are calculated in $10^{\circ} \times 10^{\circ}$ grid cells. White areas denote absolute values of $\mathrm{O}_{3}-\mathrm{CO}$ correlation coefficients less than 0.2 .

cific Ocean. By contrast, the correlations in these regions in GMI/fvGCM and GMI/GEOS-4 are either weak or positive. The convection in fvGCM is much weaker than in GEOS-4 or MERRA except at SH midlatitudes and over the Tibetan Plateau (not shown). MERRA has the strongest convection in Central America, the tropical western Pacific Ocean, the tropical eastern Pacific Ocean, the tropical western Atlantic Ocean, the tropical eastern Indian Ocean, and the Bay of Bengal. These differences of convective mass fluxes result in broader regions with negative $\mathrm{O}_{3}-\mathrm{CO}$ correlations in the tropics in GMI/MERRA than those in GMI/fvGCM and GMI/GEOS-4. Kim et al. (2013) also simulated different $\mathrm{O}_{3}-$ $\mathrm{CO}$ correlations in some tropical regions with GEOS-Chem driven by GEOS-4 and GEOS-5 meteorological data sets because of the model transport error associated with deep convection.

\subsection{Evaluation of GMI $\mathrm{O}_{3}-\mathrm{CO}$ correlations with TES observations}

Figures 13 and 14 show the $\mathrm{O}_{3}-\mathrm{CO}$ correlation coefficients $(R)$ and linear regression slopes $\left(\mathrm{dO}_{3} / \mathrm{dCO}\right)$, respectively, at $618 \mathrm{hPa}$ as determined by TES observations for July-August 2005 and corresponding GMI CTM results with 3-hourly output sampled along the TES orbit tracks. Values are calculated in $10^{\circ} \times 10^{\circ}$ grid cells. The regions $>60^{\circ} \mathrm{S}$ and $>60^{\circ} \mathrm{N}$ are excluded in this study because $\mathrm{O}_{3}$ and $\mathrm{CO}$ concentrations over these regions are low (Fig. 8), and absolute co-variances of $\mathrm{O}_{3}$ and $\mathrm{CO}$ over these regions are also low (not shown). Therefore, as suggested by Voulgarakis et al. (2011), discrepancies in these regions are not scientifically important in terms of the $\mathrm{O}_{3}-\mathrm{CO}$ correlation. Since only 2 months of $\mathrm{TES}_{3}$ and $\mathrm{CO}$ observations were used, the correlation patterns are somewhat patchy, and correlations are weak $(|R|<0.2)$ over more than half of the globe. Using TES data for July-August over 5 years improves the consistency of the correlation patterns (Fig. 15), as discussed later. TESobserved $\mathrm{O}_{3}$ and $\mathrm{CO}$ concentrations show the highest correlations ( $R$ up to 0.6 ) with large slopes over the western Pacific and relatively high correlations $(R=0.2-0.4)$ with relatively large slopes over North America; the Middle East; northern South America; central and southern Africa; and continental outflow regions, e.g., the western North Pacific Ocean, western Indian Ocean, subtropical South Atlantic Ocean, tropical eastern Pacific, and western North Atlantic (Figs. 13 and 14). Negative correlations were observed over the Tibetan Plateau $(R<-0.6)$, northern Africa, and SH mid- 
TES slope

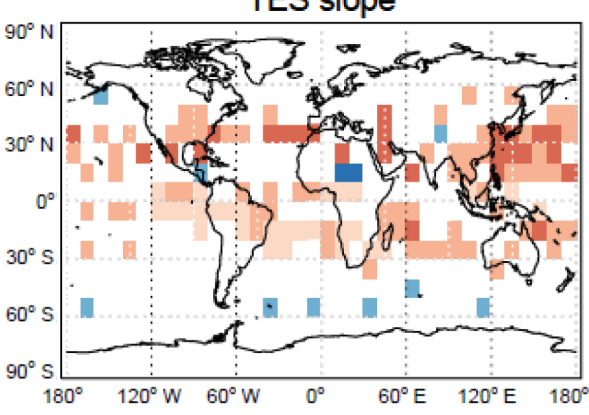

GMI/GEOS4 slope
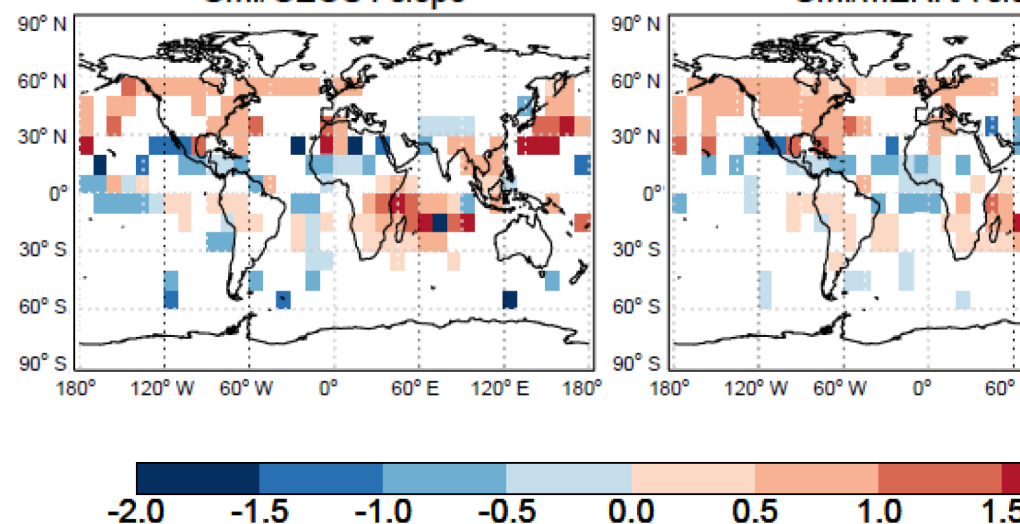

GMI/fvGCM slope

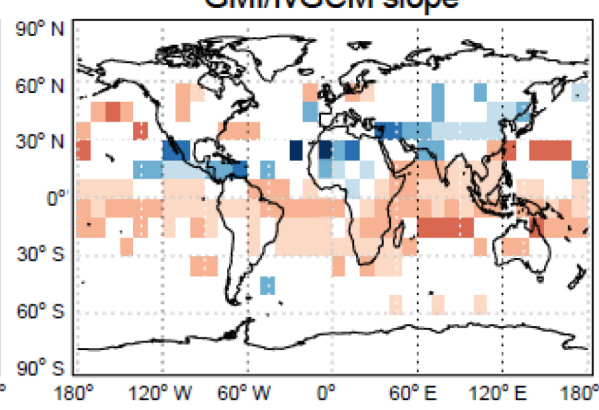

GMI/MERRA slope

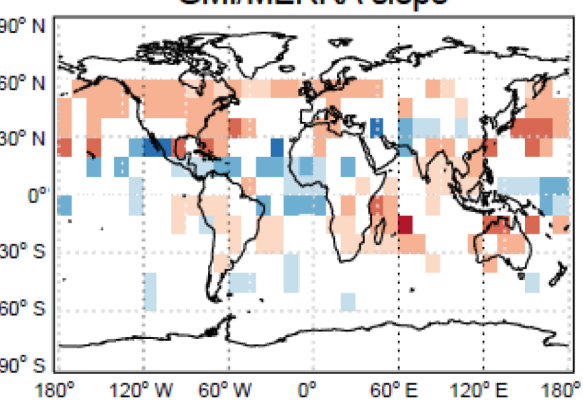

Figure 14. Same as Fig. 13 but for linear regression slopes $\mathrm{dO}_{3} / \mathrm{dCO}$.

latitudes $(R<-0.4)$ (Fig. 13). Global TES $\mathrm{O}_{3}-\mathrm{CO}$ correlation patterns and magnitudes are similar to those reported by Zhang et al. (2006) and Voulgarakis et al. (2011). The slope patterns (Fig. 14) follow the correlation ones (Fig. 13), suggesting that the slopes of the regression lines are useful indicators of the correlation strength.

The GMI-simulated $\mathrm{O}_{3}-\mathrm{CO}$ correlation coefficients and linear regression slopes $\left(\mathrm{dO}_{3} / \mathrm{dCO}\right)$ calculated from each of the three model outputs sampled along the TES orbit tracks show similar global patterns but overall weaker correlations (Fig. 13) and smaller slopes (Fig. 14) than nonsampled raw model results (Fig. 12) due to spatiotemporal sampling and application of TES averaging kernels. All simulations capture the TES-observed positive $\mathrm{O}_{3}-\mathrm{CO}$ correlations in various regions. On the other hand, all simulations indicate strong negative correlations over the Tibetan Plateau and tropical convective regions where TES misses such correlations or only shows much weaker negative correlations in much narrower areas.

To get a more statistically robust view of TES $\mathrm{O}_{3}-\mathrm{CO}$ correlations, we conduct a similar analysis using multi-year observations. Figure 15 shows the $\mathrm{O}_{3}-\mathrm{CO}$ correlation coefficients $(R)$ and linear regression slopes $\left(\mathrm{dO}_{3} / \mathrm{dCO}\right)$ at $618 \mathrm{hPa}$ as determined by TES $\mathrm{O}_{3}$ and CO retrievals for JulyAugust over 5 years (2005-2009). Values are calculated in $4^{\circ} \times 5^{\circ}$ grid cells. The global distributions provide more de- tails and are consistent with the coarse patterns for JulyAugust 2005 shown in Figs. 13 and 14. The negative correlations over the Tibetan Plateau and northern Africa are more apparent than those using the TES data only for July-August 2005 (Fig. 13). Overall our results of multi-year (2005-2009) $\mathrm{O}_{3}-\mathrm{CO}$ correlation coefficients at $618 \mathrm{hPa}$ for July-August are similar to those inferred from the mean mid-tropospheric (400-800 hPa) TES $\mathrm{O}_{3}$ and $\mathrm{CO}$ concentrations averaged over July-August 2005-2008 (Voulgarakis et al., 2011).

\section{Sensitivity of $\mathrm{O}_{3}-\mathrm{CO}$ correlations to emissions}

In order to understand how $\mathrm{O}_{3}-\mathrm{CO}$ correlation patterns are driven by emissions, we examine the sensitivity of $\mathrm{O}_{3}-\mathrm{CO}$ correlations to emission types in the GMI model driven by the MERRA meteorological fields, which represent the state of the art of GEOS DAS at the time of this study. Figures 1619 show the mean changes in $\mathrm{O}_{3}$ and $\mathrm{CO}$ concentrations (ppbv) and their correlation coefficients, as well as the areas where correlation signs change relative to the standard simulation at $618 \mathrm{hPa}$ when each emission type (fossil fuel, biomass burning, biogenic, and lightning $\mathrm{NO}_{x}$ emissions) is excluded in the model for July-August 2005. Figure 20 shows the $\mathrm{O}_{3}-\mathrm{CO}$ correlation coefficients $(R)$ at $618 \mathrm{hPa}$ in the standard simulation and when each emission type is ex- 

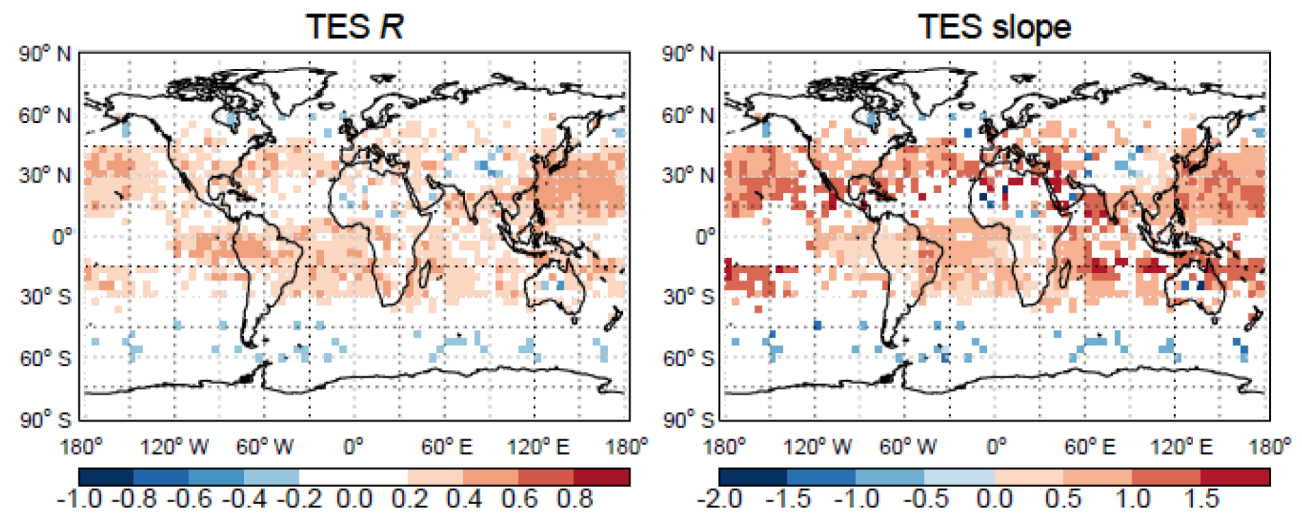

Figure 15. $\mathrm{O}_{3}-\mathrm{CO}$ correlation coefficients $(R)$ and linear regression slopes $\left(\mathrm{dO}_{3} / \mathrm{dCO}\right)$ at $618 \mathrm{hPa}$ as determined by $\mathrm{O}_{3}$ and $\mathrm{CO}$ observations from TES during July-August 2005-2009. Results are calculated in $4^{\circ} \times 5^{\circ}$ grid cells. White areas denote absolute values of $\mathrm{O}_{3}-\mathrm{CO}$ correlation coefficients less than 0.2 .

cluded. Results are calculated using 3-hourly model output. These figures provide the context for discussions in this section.

Fossil fuel emissions substantially increase $\mathrm{O}_{3}$ (by $\sim 5-$ 20 ppbv) and $\mathrm{CO}$ (by $\sim 10-30 \mathrm{ppbv}$ ) in the $\mathrm{NH}$, notably over the Asian and North American continental outflow regions (Fig. 16a, b). Fossil fuel emissions lead to strengthened $\mathrm{O}_{3}-$ $\mathrm{CO}$ correlations, with correlation signs changing from negative to positive over the Asian and North American outflow regions (Figs. 16cd and 20b). Such effects are also seen over Europe, the Arabian Sea, the northern Bay of Bengal, and the eastern North Pacific (Fig. 16cd). Fossil fuel emissions result in stronger negative $\mathrm{O}_{3}-\mathrm{CO}$ correlations over part of the Asian continent (Fig. 16c). This is especially true over the Tibetan Plateau, where low-level convergence transports air masses with low $\mathrm{O}_{3}$ and high $\mathrm{CO}$ to the middle troposphere.

Biomass burning emissions increase $\mathrm{O}_{3}$ (by $\sim 2-10 \mathrm{ppbv}$ ) and $\mathrm{CO}$ (by $>25 \mathrm{ppbv}$ ) in the easterly outflow in tropical South America and central Africa, in the westerly outflow in the southern subtropics, and over Indonesia (Fig. 17a, b). They are responsible for the positive correlations at $\mathrm{SH}$ mid- and high latitudes (Figs. 17c, d and 19c). Without biomass burning emissions, $\mathrm{O}_{3}-\mathrm{CO}$ correlations over the westerly outflow in the southern subtropics and most of the SH mid- and high latitudes would be negative or very weak (Figs. 17c and 20c). By contrast, biomass burning emissions degrade an already strong correlation from fossil fuel emissions in the $\mathrm{NH}$ (e.g., over part of the tropical western Pacific, Bay of Bengal, NH subtropical Atlantic, and especially NH high latitudes; Fig. 17d). In the tropics, biomass burning emissions strengthen the positive correlations in Indonesia and weaken the negative correlations over the tropical South American outflow region. In the two models of Voulgarakis et al. (2011), biomass burning emissions have the largest impact on the $\mathrm{O}_{3}-\mathrm{CO}$ correlations in the tropics, especially downwind of central Africa and South America where biomass burning emissions changed the correlation sign from negative to positive. Our results show no apparent changes in the $\mathrm{O}_{3}-\mathrm{CO}$ correlation signs (negative) in these downwind regions. This may reflect the differences in biomass burning emissions and/or chemical mechanisms used in the two studies.

Biogenic emissions increase $\mathrm{O}_{3}$ concentrations at $618 \mathrm{hPa}$ by $\sim 2-6 \mathrm{ppbv}$ in the $\mathrm{NH}$ subtropics and at $\mathrm{NH}$ midlatitudes but decrease $\mathrm{O}_{3}$ concentrations by up to $\sim 10 \mathrm{ppbv}$ in tropical South America, tropical Africa, and Indonesia (Fig. 18a). The latter mainly reflects the fact that $\mathrm{O}_{3}$ is consumed during the atmospheric oxidation process of isoprene under low$\mathrm{NO}_{x}$ conditions (Fan and Zhang, 2004; Seinfeld and Pandis, 1998). Biogenic emissions have large positive impacts on $\mathrm{CO}$ concentrations in the easterly and westerly outflow regions of South America and Africa, in the North American outflow, over southwestern China and Indonesia, and in the SH background (Fig. 18b). The $\mathrm{O}_{3}-\mathrm{CO}$ correlations in the model show less sensitivity to biogenic emissions than to other emission types (Figs. 18c and 20d). Nevertheless, biogenic emissions lead to strong negative $\mathrm{O}_{3}-\mathrm{CO}$ correlations over the tropical eastern Pacific Ocean due to reduced $\mathrm{O}_{3}$ and enhanced $\mathrm{CO}$ concentrations associated with these emissions (Figs. 18c, d and 20d). Such effects are also seen over central Africa, easterly South American outflow, westerly South American outflow, Indonesia, and the subtropical western Pacific.

Lightning $\mathrm{NO}_{x}$ emissions increase $\mathrm{O}_{3}$ concentrations at $618 \mathrm{hPa}$ by up to $\sim 15-25 \mathrm{ppbv}$ in the NH subtropics and at $\mathrm{NH}$ midlatitudes, and by up to $\sim 15-30 \mathrm{ppbv}$ in the SH tropics and subtropics (Fig. 19a). Such increases are relatively larger in those regions with subsiding air from the UT (cf. Fig. 9, bottom right panel), where the largest effect of lightning $\mathrm{NO}_{x}$ emissions occurs. The resulting increase in $\mathrm{OH}$ concentrations leads to a general decrease in $\mathrm{CO}$ concentrations with maximum effects in the tropics and $\mathrm{SH}$ subtropics (Fig. 19a, b). Consequently, lightning $\mathrm{NO}_{x}$ emissions weaken both the positive $\mathrm{O}_{3}-\mathrm{CO}$ correlations at mid- and 

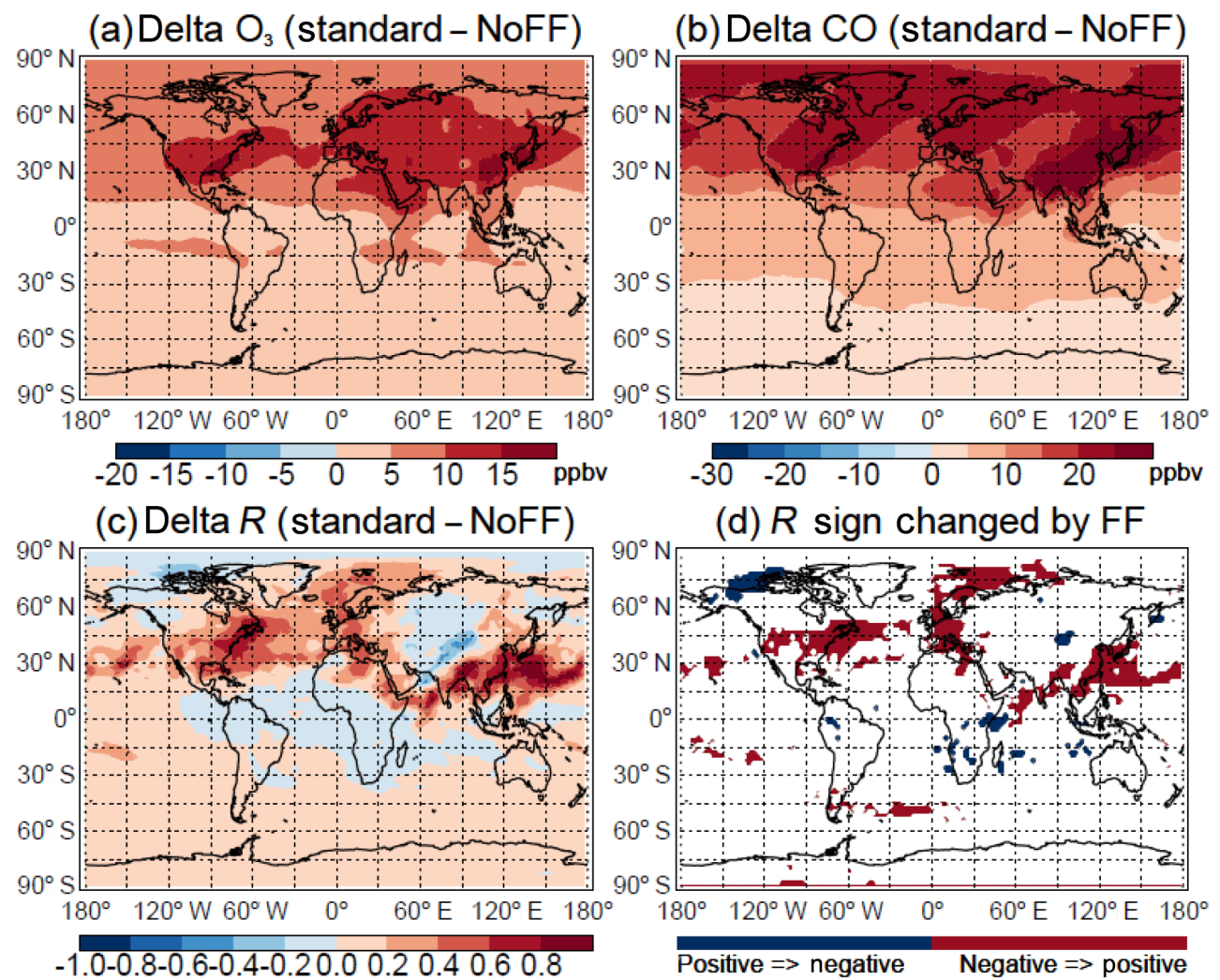

Figure 16. Sensitivity of $\mathrm{O}_{3}$, CO, and their correlations to fossil fuel (FF) emissions during July-August 2005. The plots show the mean differences in (a) $\mathrm{O}_{3}$, (b) $\mathrm{CO}$ mixing ratios (ppbv), and (c) $\mathrm{O}_{3}-\mathrm{CO}$ correlation coefficients $(R)$ at $618 \mathrm{hPa}$ between the standard GMI/MERRA simulation and a simulation where fossil fuel emissions are suppressed (NoFF) in the model. Also shown in (d) are the areas with changed correlation signs. Results are calculated using 3-hourly model output.

high latitudes and the negative correlations in the tropics (Figs. 19c and d, and 20e). They alter the correlation signs from positive to negative in various areas where the correlations are generally weak (Fig. 19d). Our results are in contrast with those of Voulgarakis et al. (2011), who showed that lightning $\mathrm{NO}_{x}$ emissions appeared to increase the $\mathrm{O}_{3}-\mathrm{CO}$ correlations $(400-800 \mathrm{hPa})$ in various regions (e.g., tropical eastern Pacific, NH continental outflow regions). These may partly reflect the differences in the altitude and strength of lightning $\mathrm{NO}_{x}$ emissions.

\section{Summary and conclusions}

We have examined the capability of the GMI CTM to reproduce the global mid-tropospheric $\mathrm{O}_{3}-\mathrm{CO}$ correlations from the TES instrument on board the NASA Aura satellite during boreal summer (July-August). The model was driven by three meteorological data sets (fvGCM for 1995, GEOS-4 for 2005, MERRA for 2005), allowing us to examine the sensitivity of model $\mathrm{O}_{3}-\mathrm{CO}$ correlations to input meteorological data. To understand how various emissions drive global $\mathrm{O}_{3}-$ $\mathrm{CO}$ correlation patterns, we also investigated the sensitivity of GMI/MERRA model-calculated $\mathrm{O}_{3}$ and $\mathrm{CO}$ concentrations and their correlations to emission types.

We evaluated GMI-simulated tropospheric $\mathrm{O}_{3}$ vertical profiles and tropospheric $\mathrm{O}_{3}$ columns with those from ozonesonde and satellite observations, respectively. To aid in the evaluation, model simulations of radionuclide tracers $\left({ }^{222} \mathrm{Rn},{ }^{210} \mathrm{~Pb}\right.$, and $\left.{ }^{7} \mathrm{Be}\right)$ were used to illustrate the differences in convection, stratospheric influence, and large-scale subsidence among three meteorological data sets. Among the three GMI simulations, GMI/GEOS-4-simulated $\mathrm{O}_{3}$ concentrations are in best agreement with the observations. GMI/MERRA underestimates $\mathrm{O}_{3}$ in the $\mathrm{NH}$ high-latitude UT due to weak STE and overestimates $\mathrm{O}_{3}$ in the SH subtropics. The latter is due to a combination of excessive influences from lightning $\mathrm{NO}_{x}$ emissions and STE (or subsidence), as well as the shallower convection resulting in less low- $\mathrm{O}_{3}$ air lifted from the LT to MT/UT. The latitudinal distribution of model biases in TOCs relative to satellite observations is consistent with the results from model evaluations with ozonesonde $\mathrm{O}_{3}$ profiles.

We evaluated GMI-simulated $\mathrm{O}_{3}$ and $\mathrm{CO}$ concentrations with TES observations at $618 \mathrm{hPa}$, where TES has most sensitivity. TES observed $\mathrm{O}_{3}$ enhancements over the NH mid- 
(a) Delta $\mathrm{O}_{3}$ (standard - NoBB)

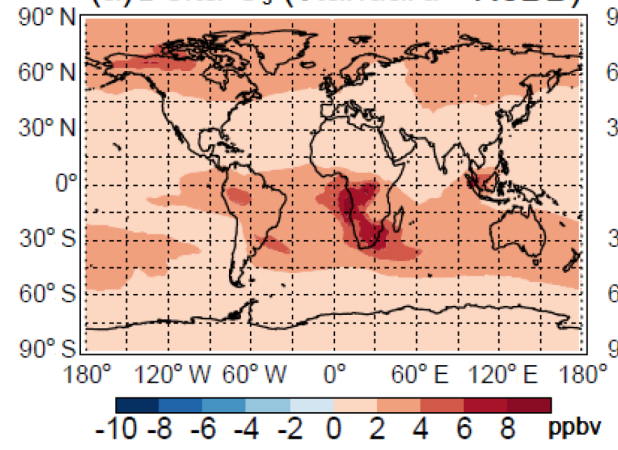

(c) Delta $R$ (standard - NoBB)

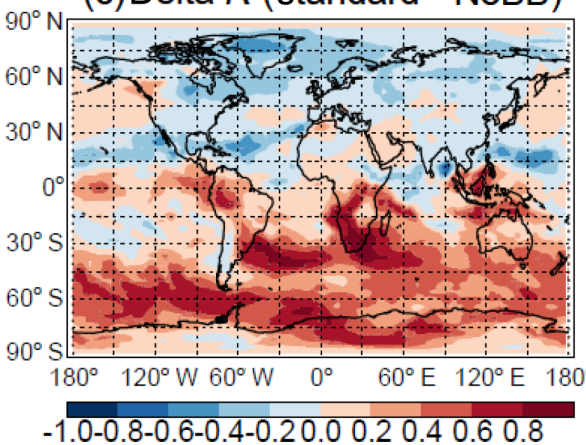

(b)Delta CO (standard - NoBB)

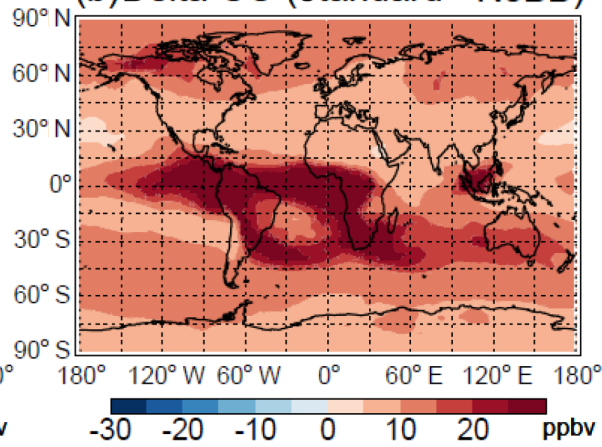

(d) $R$ sign changed by $\mathrm{BB}$

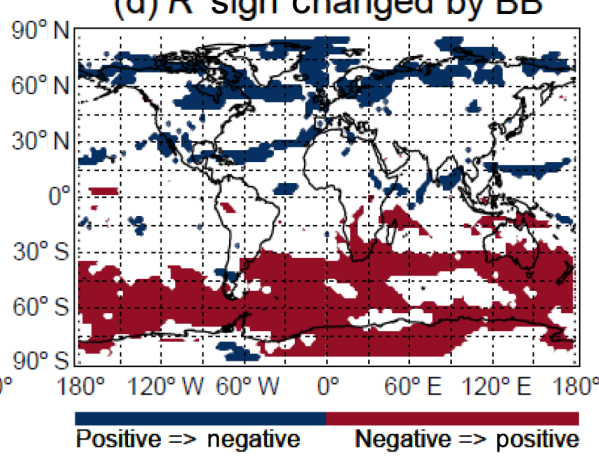

Figure 17. Same as Fig. 16 but for the sensitivity of $\mathrm{O}_{3}, \mathrm{CO}$, and their correlations at $618 \mathrm{hPa}$ to biomass burning (BB) emissions.

(a)Delta $\mathrm{O}_{3}$ (standard - NoBG)

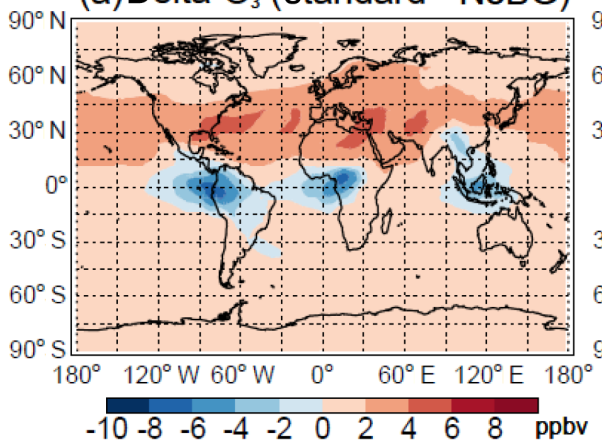

(c) Delta $R$ (standard - NoBG)

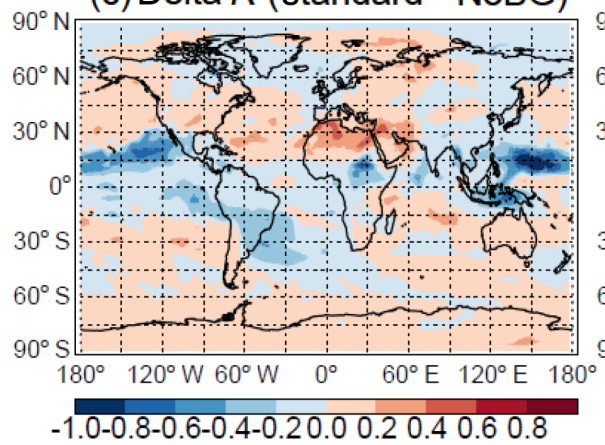

(b) Delta CO (standard - NoBG)

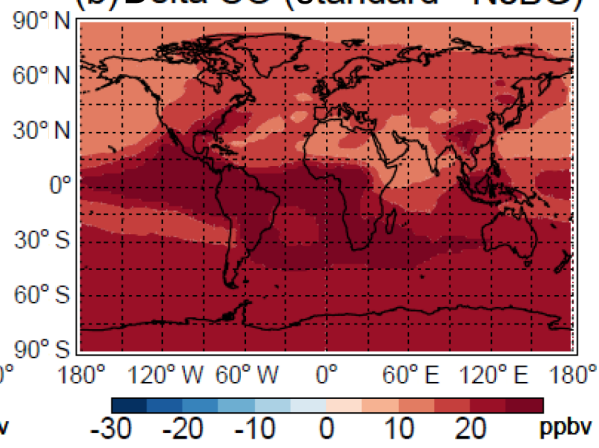

(d) $R$ sign changed by $\mathrm{BG}$

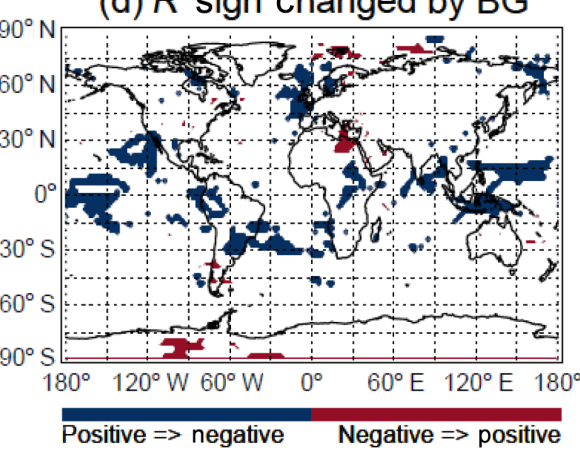

Figure 18. Same as Fig. 16 but for the sensitivity of $\mathrm{O}_{3}, \mathrm{CO}$, and their correlations at $618 \mathrm{hPa}$ to biogenic (BG) emissions. 
(a) Delta $\mathrm{O}_{3}$ (standard - NoLNOx)

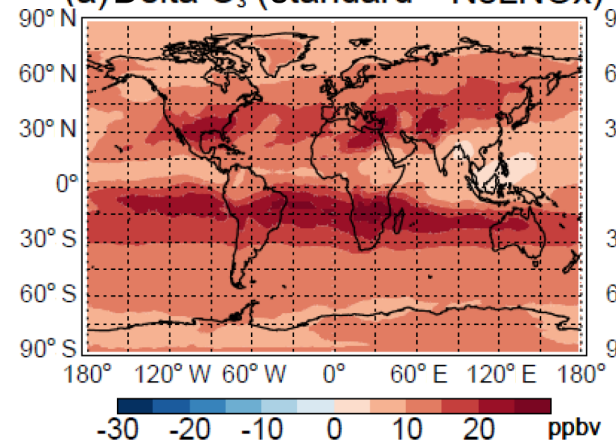

(b) Delta CO (standard - NoLNOx)

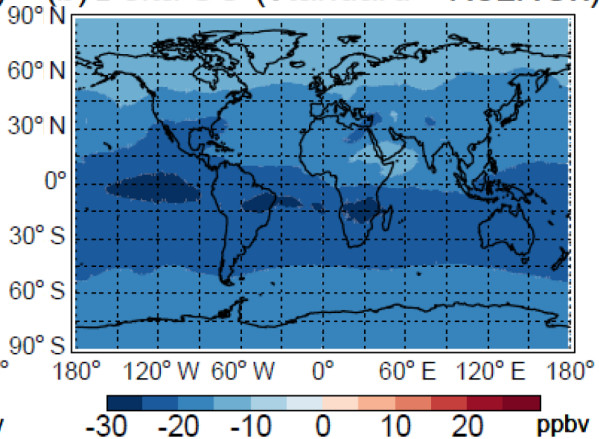

(c) Delta $R$ (standard - NoLNOx)
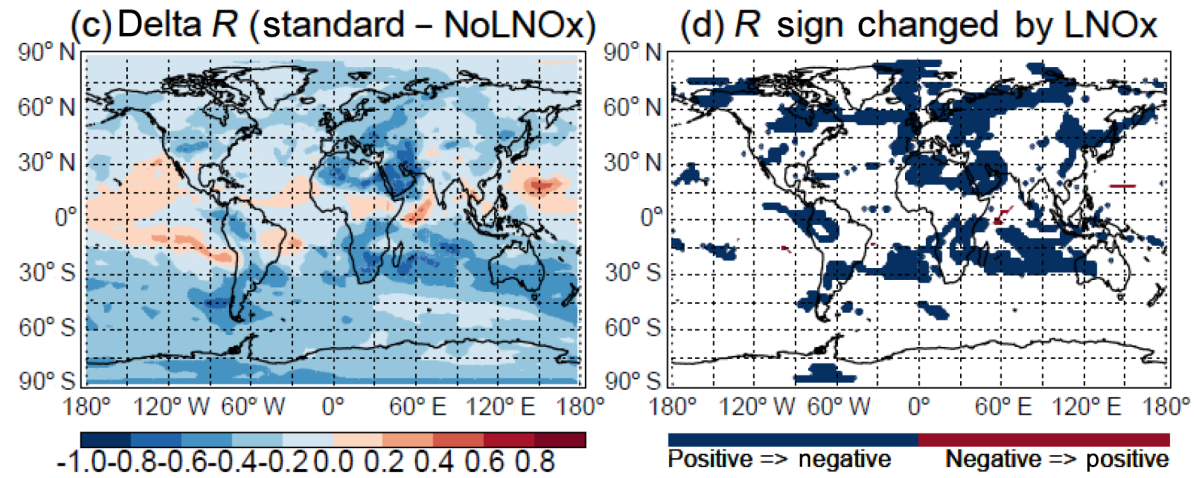

Figure 19. Same as Fig. 16 but for the sensitivity of $\mathrm{O}_{3}, \mathrm{CO}$, and their correlations at $618 \mathrm{hPa}$ to lightning $\mathrm{NO}_{x}\left(\mathrm{LNO}_{x}\right)$ emissions.

latitudes (including continental outflow regions), the Middle East, subtropical southern Africa, and the subtropical South Atlantic. All simulations capture well the global spatial distribution of $\mathrm{O}_{3}$ at $618 \mathrm{hPa}$ but appear to underestimate TES $\mathrm{O}_{3}$ observations over southern Africa and its outflow region. GMI/fvGCM simulates the highest $\mathrm{O}_{3}$ concentrations at $\mathrm{NH}$ mid- and high latitudes, especially over the Asian continent due to strong STE, whereas it simulates the lowest $\mathrm{O}_{3}$ concentrations in the southern tropics and subtropics due to weak STE and low lightning $\mathrm{NO}_{x}$ emissions. GMI/MERRA simulates the highest $\mathrm{O}_{3}$ concentrations in the southern subtropics, especially in southern Africa due to high lightning $\mathrm{NO}_{x}$ emissions and, to a lesser extent, strong convection. GMI/fvGCM underestimates the $\mathrm{O}_{3}$ minimum in the tropical western Pacific and eastern Indian Ocean. Considering the positive bias in TES $\mathrm{O}_{3}$ at $\mathrm{NH}$ midlatitudes, GMI/fvGCM appears to overestimate $\mathrm{O}_{3}$ over the East Asian outflow region due to too-fast STE, whereas GMI/GEOS4 and GMI/MERRA simulate $\mathrm{O}_{3}$ enhancements reasonably well in East Asia and its downwind regions. All three simulations significantly underestimate TES-observed CO enhancements at $\mathrm{NH}$ midlatitudes but simulate better $\mathrm{CO}$ enhancements over the tropical biomass burning regions.

The three GMI simulations all show strong positive $\mathrm{O}_{3}-$ $\mathrm{CO}$ correlations at $618 \mathrm{hPa}$ over the $\mathrm{NH}$ midlatitude continental outflow regions and the SH biomass burning outflow regions, as shown by TES observations. Generally, positive $\mathrm{O}_{3}-\mathrm{CO}$ correlations are simulated downwind of pol- luted regions due to photochemical production of $\mathrm{O}_{3}$ from its precursors. However, owing to significant influences from the stratosphere and subsidence from the UT/LS over these regions, mixing of stratospheric air with polluted (anthropogenic or biomass burning) air masses is associated with strong positive $\mathrm{O}_{3}-\mathrm{CO}$ correlations with large $\mathrm{dO}_{3} / \mathrm{dCO}$ enhancement ratios. Strong positive $\mathrm{O}_{3}-\mathrm{CO}$ correlations are also simulated over the Indonesian biomass burning region where deep convection occurs, but the $\mathrm{dO}_{3} / \mathrm{dCO}$ enhancement ratios are smaller than those in the $\mathrm{NH}$ midlatitude continental outflow regions. The latter reflects the lower efficiency of $\mathrm{NO}_{x}$ emissions from biomass burning. Strong negative $\mathrm{O}_{3}-\mathrm{CO}$ correlations over northern and central Africa, the tropical Atlantic, and the tropical eastern and western Pacific in all simulations result from convective transport of biomass burning air masses with low $\mathrm{O}_{3}$ and consumption of $\mathrm{O}_{3}$ along with production of $\mathrm{CO}$ due to oxidation of biogenic hydrocarbons (e.g., isoprene under low- $\mathrm{NO}_{x}$ conditions). The simulated negative $\mathrm{O}_{3}-\mathrm{CO}$ correlations over the Asian continent, including the Middle East, are partly attributed to stratospheric influence and/or subsidence from the UT/LS. High $\mathrm{O}_{3}$ and low $\mathrm{CO}$ associated with stratospherically influenced air lead to strong negative correlations with large $\mathrm{dO}_{3} / \mathrm{dCO}$ ratios. On the other hand, over southwestern China, monsoonal convective lifting of air masses with high $\mathrm{CO}$ and low $\mathrm{O}_{3}$ results in negative $\mathrm{O}_{3}-\mathrm{CO}$ correlations. By contrast, TES $\mathrm{O}_{3}$ and $\mathrm{CO}$ concentrations at $618 \mathrm{hPa}$ either miss such negative correlations (i.e., tropical convective 
(a) Standard

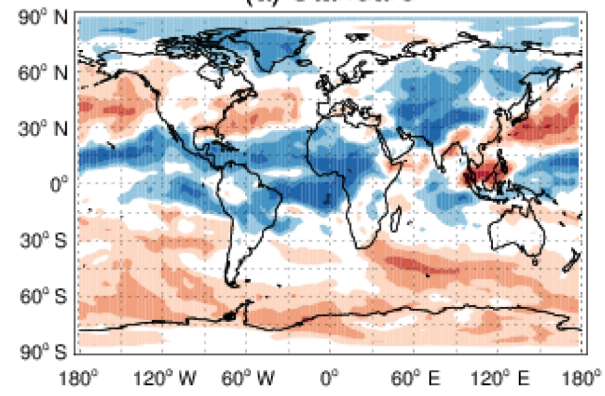

(b) NoFF $R$

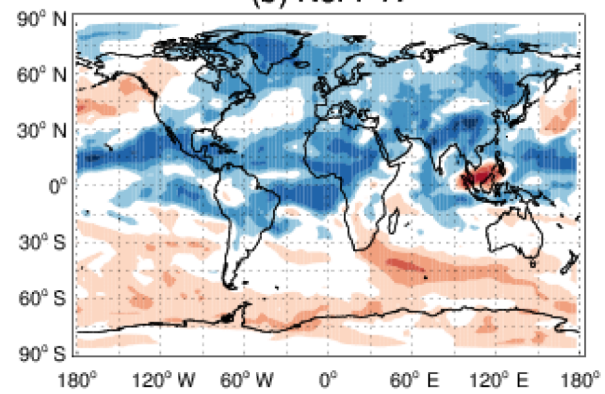

(d) NoBG $R$

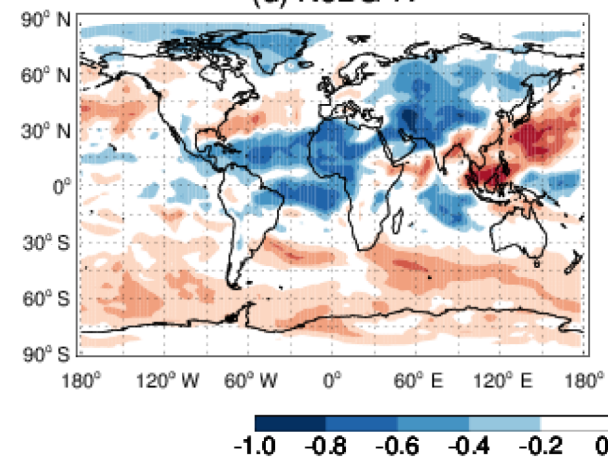

(c) NoBB $R$

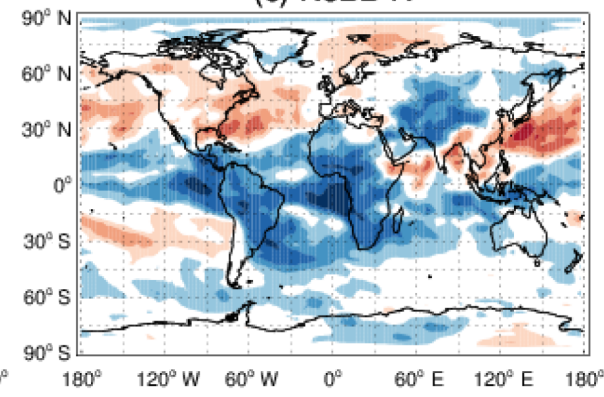

(e) NoLNOx R

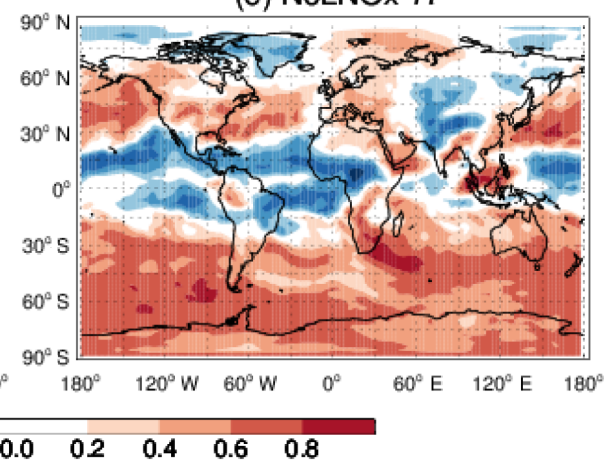

Figure 20. GMI/MERRA-simulated $\mathrm{O}_{3}-\mathrm{CO}$ correlations $(R)$ at $618 \mathrm{hPa}$ (a) in the standard simulation and (b-e) when fossil fuel (FF), biomass burning $(\mathrm{BB})$, biogenic $(\mathrm{BG})$, and lightning $\mathrm{NO}_{x}\left(\mathrm{LNO}_{x}\right)$ emissions are individually suppressed (NoFF, NoBB, NoBG, and $\mathrm{NoLNO}_{x}$, respectively) in the model during July-August 2005. Results are calculated using 3-hourly model output. White areas denote absolute values of $\mathrm{O}_{3}-\mathrm{CO}$ correlation coefficients less than 0.2 .

regions) or only show weak negative correlations over much narrower areas (i.e., the Tibetan Plateau and northern Africa).

TES-observed $\mathrm{O}_{3}$ and $\mathrm{CO}$ concentrations at $618 \mathrm{hPa}$ show the highest positive correlations with large regression slopes over the western Pacific and relatively high correlations over North America, the Middle East, northern South America, central and southern Africa, and continental outflow regions. Negative correlations are observed in parts of the Asian continent (Tibetan Plateau), northern Africa, and SH midlatitudes. All model output sampled along the TES orbit track captures the observed positive $\mathrm{O}_{3}-\mathrm{CO}$ correlations over the NH midlatitude continental outflow regions, southern Africa, the western Indian Ocean, the subtropical South Atlantic, northern South America, and the tropical eastern Pacific. While all simulations show strong negative correlations over the Tibetan Plateau, northern Africa, the subtropical eastern North Pacific, and the Caribbean, TES $\mathrm{O}_{3}$ and $\mathrm{CO}$ concentrations at $618 \mathrm{hPa}$ only show weak negative correlations over much narrower areas (i.e., the Tibetan Plateau and northern Africa).

We performed sensitivity simulations with GMI/MERRA to investigate the effect of individual emission types on model-calculated $\mathrm{O}_{3}-\mathrm{CO}$ correlations at $618 \mathrm{hPa}$. Results show that fossil fuel emissions increase global $\mathrm{O}_{3}$ and $\mathrm{CO}$ concentrations and are responsible for the strong positive correlations over the NH continental outflow regions. Both biomass burning and biogenic emissions significantly increase global $\mathrm{CO}$ concentrations. Biomass burning emissions increase $\mathrm{O}_{3}$ concentrations in the easterly outflow in tropical South America and central Africa, in the westerly outflow in 
the southern subtropics, and over Indonesia. Biogenic emissions increase $\mathrm{O}_{3}$ concentrations in the $\mathrm{NH}$ subtropics and at $\mathrm{NH}$ midlatitudes but decrease $\mathrm{O}_{3}$ concentrations in tropical South America, tropical Africa, and Indonesia. The decreases mainly reflect the fact that $\mathrm{O}_{3}$ is consumed during the atmospheric oxidation process of isoprene under low- $\mathrm{NO}_{x}$ conditions. Biomass burning emissions are responsible for the positive correlations at SH mid- and high latitudes and negative correlations over part of the tropical western Pacific, the Bay of Bengal, the NH subtropical Atlantic, and NH high latitudes. Biogenic emissions have relatively smaller impact on the correlations than other emissions do but are largely responsible for the negative $\mathrm{O}_{3}-\mathrm{CO}$ correlations over the tropical eastern Pacific. Lightning $\mathrm{NO}_{x}$ emissions lead to large increases in $\mathrm{O}_{3}$ concentrations in the $\mathrm{NH}$ subtropics and at $\mathrm{NH}$ midlatitudes, and in the SH tropics and subtropics, especially in the regions of subsidence. We find that lightning $\mathrm{NO}_{x}$ emissions weaken both positive $\mathrm{O}_{3}-\mathrm{CO}$ correlations at mid- and high latitudes and negative correlations in the tropics and that they change weak positive correlations to negative in various areas. This result contrasts with that of previous studies.

This study demonstrates the utility of $\mathrm{O}_{3}-\mathrm{CO}$ correlations to constrain the sources of tropospheric $\mathrm{O}_{3}$ in global 3-D models. Our model simulations driven by three input meteorological data sets show significantly different global and regional distributions of $\mathrm{O}_{3}$ and $\mathrm{CO}$ concentrations during boreal summer. For instance, GMI/fvGCM simulations show higher $\mathrm{O}_{3}$ concentrations in the $\mathrm{NH}$ and lower $\mathrm{CO}$ concentrations than other simulations. Despite such differences, all simulations show similar patterns of $\mathrm{O}_{3}-\mathrm{CO}$ correlations on a global scale. The regional features of the correlations, however, are often different due to the discrepancies in various meteorological processes (e.g., convection, STE, subsidence). In particular, GMI/MERRA simulates broader areas of strong negative $\mathrm{O}_{3}-\mathrm{CO}$ correlations at $618 \mathrm{hPa}$ in the tropics than GMI/fvGCM and GMI/GEOS-4 do due to stronger tropical convection in the LT/MT. In this sense, $\mathrm{O}_{3}-\mathrm{CO}$ correlations can be used to constrain better the sources of regional tropospheric $\mathrm{O}_{3}$ in global models, especially for convective regions, than $\mathrm{O}_{3}$ and $\mathrm{CO}$ observations individually. Future work, where additional meteorological archives (e.g., GFDL AM3, ECMWF ERA-Interim) may also be incorporated, should examine the driving factors for $\mathrm{O}_{3}-\mathrm{CO}$ correlations in other seasons.

Data availability. A description of the model output and observational data used in this paper can be found in Sect. 2, and they are available upon request by contacting Hongyu Liu (hongyu.liu$1 @$ nasa.gov). For more information on the Global Modeling Initiative chemistry and transport model, refer to https://gmi.gsfc.nasa. gov/.
Competing interests. The authors declare that they have no conflict of interest.

Acknowledgements. This work was supported by the NASA Modeling, Analysis, and Prediction (MAP) Program and NASA Atmospheric Composition Modeling and Analysis Program (ACMAP). The NASA Center for Computational Sciences (NCCS) provided supercomputing resources. TES data products are distributed by the NASA Langley Atmospheric Science Data Center.

Edited by: Frank Dentener

Reviewed by: Vincent Huijnen and one anonymous referee

\section{References}

Allen, D., Pickering, K., Duncan, B., and Damon, M.: Impact of lightning NO emissions on North American photochemistry as determined using the Global Modeling Initiative (GMI) model, J. Geophys. Res., 115, D22301, https://doi.org/10.1029/2010JD014062, 2010.

Anderson, B. E., Gregory, G. L., Barrick, J. D. W., Collins, J. E. Jr., Sachse, G. W., Bagwell, D., Shipham, M. C., Bradshaw, J. D., and Sandholm, S. T.: The impact of U.S. continental outflow on ozone and aerosol distributions over the western Atlantic, J. Geophys. Res., 98, 23477-23489, https://doi.org/10.1029/93JD01208, 1993.

Beer, R.: TES on the Aura mission: Scientific objectives, measurements, and analysis overview, IEEE T. Geosci. Remote, 44, 1102-1105, https://doi.org/10.1109/tgrs.2005.863716, 2006.

Beer, R., Glavich, T. A., and Rider, D. M.: Tropospheric emission spectrometer for the Earth Observing System's Aura Satellite, Appl. Optics, 40, 2356-2367, 2001.

Benkovitz, C. M., Scholtz, M. T., Pacyna, J., Tarrasón, L., Dignon, J., Voldner, E. C., Spiro, P. A., Logan, J. A., and Graedel, T. E.: Global gridded inventories of anthropogenic emissions of sulfur and nitrogen, J. Geophys. Res., 101, 29239-29253, https://doi.org/10.1029/96JD00126, 1996.

Bey, I., Jacob, D. J., Yantosca, R. M., Logan, J. A., Field, B., Fiore, A. M., Li, Q., Liu, H., Mickley, L. J., and Schultz, M.: Global modeling of tropospheric chemistry with assimilated meteorology: Model description and evaluation, J. Geophys. Res., 106, 23073-23096, 2001.

Bloom, S., da Silva, A., Dee, D., Bosilovich, M., Chern, J.-D., Pawson, S., Schubert, S., Sienkiewicz, M., Stajner, I., Tan, W.-W., and Wu, M.-L.: Documentation and Validation of the Goddard Earth Observing System (GEOS) Data Assimilation System Version 4, Technical Report Series on Global Modeling and Data Assimilation, edited by: Suarez, M. J., NASA/TM-2005-104606, Vol. 26, NASA Goddard Space Flight Center, Greenbelt, Maryland, April 2005.

Bowman, K. W., Steck, T., Worden, H. M., Worden, J., Clough, S., and Rodgers, C.: Capturing time and vertical variability of tropospheric ozone: A study using TES nadir retrievals, J. Geophys. Res., 107, 4723, https://doi.org/10.1029/2002JD002150, 2002.

Bowman, K. W., Rodgers, D. C., Kulawik S. S., Worden, J., Sarkissian, E., Osterman, G., Steck, T., Lou, M., Eldering, A., Shephard, M., Worden, H., Lampel, M., Clough, 
S., Brown, P., Rinsland, C., Gunson, M., and Beer, R.: Tropospheric Emission Spectrometer: Retrieval method and error analysis, IEEE T. Geosci. Remote, 44, 1297-1307, https://doi.org/10.1109/TGRS.2006.871234, 2006.

Chandra, S., Ziemke, J. R., Duncan, B. N., Diehl, T. L., Livesey, N. J., and Froidevaux, L.: Effects of the 2006 El Niño on tropospheric ozone and carbon monoxide: implications for dynamics and biomass burning, Atmos. Chem. Phys., 9, 4239-4249, https://doi.org/10.5194/acp-9-4239-2009, 2009.

Chin, M., Jacob, D. J., Munger, J. W., Parrish, D. D., and Doddridge, B. G.: Relationship of ozone and carbon monoxide over North America, J. Geophys. Res., 99, 14565-14573, https://doi.org/10.1029/94JD00907, 1994.

Collins Jr., J. E., Anderson, B. E., Sachse, G. W., J. Barrick, D. W., Wade, L. O., Burney, L. G., and Hill , G. F.: Atmospheric fine structure during GTE TRACE A: Relationships among ozone, carbon monoxide, and water vapor, J. Geophys. Res., 101, 24307-24316, https://doi.org/10.1029/96JD02180, 1996.

Considine, D. B., Bergmann, D. J., and Liu, H.: Sensitivity of Global Modeling Initiative chemistry and transport model simulations of radon-222 and lead-210 to input meteorological data, Atmos. Chem. Phys., 5, 3389-3406, https://doi.org/10.5194/acp5-3389-2005, 2005.

Considine, D. B., Logan, J. A., and Olsen, M. A.: Evaluation of near-tropopause ozone distributions in the Global Modeling Initiative combined stratosphere/troposphere model with ozonesonde data, Atmos. Chem. Phys., 8, 2365-2385, https://doi.org/10.5194/acp-8-2365-2008, 2008.

Cooper, O. R., Moody, J. L., Parrish, D. D., Trainer, M., Holloway, J. S., Hübler, G., Fehsenfeld, F. C., and Stohl, A.: Trace gas composition of midlatitude cyclones over the western North Atlantic Ocean: A seasonal comparison of $\mathrm{O}_{3}$ and $\mathrm{CO}$, J. Geophys. Res., 107, 4057-4071, https://doi.org/10.1029/2001JD000902, 2002.

Dibb, J. E., Meeker, L. D., Finkel, R. C., Southon, J. R., Caffee, M. W., and Barrie, L. A.: Estimation of stratospheric input to the Arctic troposphere: ${ }^{7} \mathrm{Be}$ and ${ }^{10} \mathrm{Be}$ in aerosols at Alert, Canada, J. Geophys. Res., 99, 12855-12864, 1994.

Douglass, A. R., Prather, M. J., Hall, T. M., Strahan, S. E., Rasch, P. J., Sparling, L. C., Coy, L., and Rodriguez, J. M.: Choosing meteorological input for the global modeling initiative assessment of high-speed aircraft, J. Geophys. Res., 104, 27545-27564, 1999.

Douglass, A. R., Stolarski, R. S., Strahan, S. E., and Connell, P. S.: Radicals and reservoirs in the GMI chemistry and transport model: Comparison to measurements, J. Geophys. Res., 109, D16302, https://doi.org/10.1029/2004JD004632, 2004.

Duncan, B. N., Martin, R., Staudt, A., Yevich, R., and Logan, J.: Interannual and Seasonal Variability of Biomass Burning Emissions Constrained by Satellite Observations, J. Geophys. Res., 108, 4100, https://doi.org/10.1029/2002JD002378, 2003.

Duncan, B. N., Strahan, S. E., Yoshida, Y., Steenrod, S. D., and Livesey, N.: Model study of the cross-tropopause transport of biomass burning pollution, Atmos. Chem. Phys., 7, 3713-3736, https://doi.org/10.5194/acp-7-3713-2007, 2007a.

Duncan, B. N., Logan, J. A., Bey, I., Megretskaia, I. A., Yantosca, R. M., Novelli, P. C., Jones, N. B., and Rinsland, C. P.: Global budget of CO, 1988-1997: Source estimates and val- idation with a global model, J. Geophys. Res., 112, D22301, https://doi.org/10.1029/2007JD008459, 2007b.

Duncan, B. N., West, J. J., Yoshida, Y., Fiore, A. M., and Ziemke, J. R.: The influence of European pollution on ozone in the Near East and northern Africa, Atmos. Chem. Phys., 8, 2267-2283, https://doi.org/10.5194/acp-8-2267-2008, 2008.

Fan, J. and Zhang, R.: Atmospheric oxidation mechanism of Isoprene, Environ. Chem., 1, 140-149, https://doi.org/10.1071/EN04045, 2004.

Fehsenfeld, F. C., Daum, P., Leaitch, W. R., Trainer, M., Parrish, D. D., and Hübler, G.: Transport and processing of $\mathrm{O}_{3}$ and $\mathrm{O}_{3}$ precursors over the North Atlantic: An overview of the 1993 North Atlantic Regional Experiment (NARE) summer intensive, J. Geophys. Res., 101, 28877-28891, https://doi.org/10.1029/96JD01113, 1996.

Fishman, J. and Seiler, W.: Correlative nature of ozone and carbon monoxide in the troposphere: Implications for the tropospheric ozone budget, J. Geophys. Res., 88, 3662-3670, 1983.

Fishman, J., Wozniak, A. E., and Creilson, J. K.: Global distribution of tropospheric ozone from satellite measurements using the empirically corrected tropospheric ozone residual technique: Identification of the regional aspects of air pollution, Atmos. Chem. Phys., 3, 893-907, https://doi.org/10.5194/acp-3893-2003, 2003.

Guenther, A., Karl, T., Harley, P., Wiedinmyer, C., Palmer, P. I., and Geron, C.: Estimates of global terrestrial isoprene emissions using MEGAN (Model of Emissions of Gases and Aerosols from Nature), Atmos. Chem. Phys., 6, 3181-3210, https://doi.org/10.5194/acp-6-3181-2006, 2006.

Hack, J. J.: Parameterization of moist convection in the National Center for Atmospheric Research Community Climate Model (CCM2), J. Geophys. Res., 99, 5551-5568, 1994.

Honrath, R. E., Owen, R. C., Val Martín, M., Reid, J. S., Lapina, K., Fialho, P., Dziobak, M. P., Kleissl, J., and Westphal, D. L.: Regional and hemispheric impacts of anthropogenic and biomass burning emissions on summertime $\mathrm{CO}$ and $\mathrm{O}_{3}$ in the North Atlantic lower free troposphere, J. Geophys. Res., 109, D24310, https://doi.org/10.1029/2004JD005147, 2004.

Hsu, J., Prather, M. J., Wild, O., Sundet, J. K., Isaksen, I. S. A., Browell, E. V., Avery, M. A., and Sachse, G. W.: Are the TRACE-P measurements representative of the western Pacific during March 2001?, J. Geophys. Res., 109, D02314, https://doi.org/10.1029/2003JD004002, 2004.

Jacob D. J. and Wofsy, S. C.: Budgets of Reactive Nitrogen, Hydrocarbons, and Ozone Over the Amazon Forest During the Wet Season, J. Geophys. Res., 95, 16737-16754, 1990.

Jacob, D. J., Prather, M. J., Rasch, P. J., Shia, R. L., Balkanski, Y., J., Beagley, S. R., Bergmann, D. J., Blackshear, W. T., Brown, M., Chiba, M., Chipperfield, M. P., Degrandpre, J., Dignon, J. E., Feichter, J., Genthon, C., Grose, W. L., Kasibhatla, P. S., Kohler, I., Kritz, M. A., Law, K., Penner, J. E., Ramonet, M., Reeves, C. E., Rotman, D. A., Stockwell, D. Z., Vanvelthoven, P. F. J., Verver, G., Wild, O., Yang, H., and Zimmermann, P.: Evaluation and inter-comparison of global atmospheric transport models using ${ }^{222} \mathrm{Rn}, 102$, 5953-5970, 1997.

Jaffe, D. A., Honrath, R. E., Zhang, L., Akimoto, H., Shimizu, A., Mukai, H., Murano, K., Hatakeyama, S., and Merrill, J.: Measurements of $\mathrm{NO}, \mathrm{NO}_{y}, \mathrm{CO}$ and $\mathrm{O}_{3}$ and estimation of the ozone production rate at Oki Island, Japan, during PEM-West, J. Geo- 
phys. Res., 101, 2037-2048, https://doi.org/10.1029/95JD01699, 1996.

Junhua Liu, Logan, J. A., Jones, D. B. A., Livesey, N. J., Megretskaia, I., Carouge, C., and Nedelec, P.: Analysis of CO in the tropical troposphere using Aura satellite data and the GEOSChem model: insights into transport characteristics of the GEOS meteorological products, Atmos. Chem. Phys., 10, 1220712232, https://doi.org/10.5194/acp-10-12207-2010, 2010.

Kim, P. S., Jacob, D. J., Liu, X., Warner, J. X., Yang, K., Chance, K., Thouret, V., and Nedelec, P.: Global ozone-CO correlations from OMI and AIRS: constraints on tropospheric ozone sources, Atmos. Chem. Phys., 13, 9321-9335, https://doi.org/10.5194/acp13-9321-2013, 2013.

Kinnison, D. E., Connell, P. S., Rodriguez, J. M., Rotman, D. A., Considine, D. B., Tannahil, J., Ramaroson, R., Rasch, P. J., Douglass, A. R., Baughcum, S. L., Coy, L., Waugh, D. W., Kawa, S. R., and Prather, M. J.: The Global Modeling Initiative assessment model: Application to high-speed civil transport perturbation, J. Geophys. Res., 106, 1693-1711, https://doi.org/10.1029/2000JD900406, 2001.

Koch, D. M., Jacob, D. J., and Graustein, W. C.: Vertical transport of tropospheric aerosols as indicated by ${ }^{7} \mathrm{Be}$ and ${ }^{210} \mathrm{~Pb}$ in a chemical tracer model, J. Geophys. Res., 101, 18651-18666, https://doi.org/10.1029/96JD01176, 1996.

Li, Q., Jacob, D. J., Bey, I., Palmer, P. I., Duncan, B. N., Field, B. D., Martin, R. V., Fiore, A. M., Yantosca, R. M., Parrish, D. D., Simmonds, P. G., and Oltmans, S. J.: Transatlantic transport of pollution and its effects on surface ozone in Europe and North America, J. Geophys. Res., 107, 4166-4190, https://doi.org/10.1029/2001JD001422, 2002.

Lin, S.-J. and Rood, R. B.: Multidimensional flux-form semiLagrangian transport schemes, Mon. Weather Rev., 124, 20462070, 1996.

Liu, H., Jacob, D. J., Bey, I., and Yantosca, R. M.: Constraints from ${ }^{210} \mathrm{~Pb}$ and ${ }^{7} \mathrm{Be}$ on wet deposition and transport in a global three-dimensional chemical tracer model driven by assimilated meteorological fields, J. Geophys. Res., 106, 1210912128, https://doi.org/10.1029/2000JD900839, 2001.

Liu, H., Considine, D. B., Horowitz, L. W., Crawford, J. H., Rodriguez, J. M., Strahan, S. E., Damon, M. R., Steenrod, S. D., Xu, X., Kouatchou, J., Carouge, C., and Yantosca, R. M.: Using beryllium-7 to assess cross-tropopause transport in global models, Atmos. Chem. Phys., 16, 4641-4659, https://doi.org/10.5194/acp-16-4641-2016, 2016.

Logan, J. A.: An analysis of ozonesonde data for the troposphere: Recommendations for testing 3-D models and development of a gridded climatology for tropospheric ozone, J. Geophys. Res., 104, 16115-16149, 1999.

Lopez, J. P., Luo, M., Christensen, L. E., Loewenstein, M., Jost, H., Webster, C. R., and Osterman, G.: TES carbon monoxide validation during two AVE campaigns using the Argus and ALIAS instruments on NASA's WB-57F, J. Geophys. Res., 113, D16S47, https://doi.org/10.1029/2007JD008811, 2008.

Luo, M., Rinsland, C. P., Rodgers, C. D., Logan, J. A., Worden, H., Kulawik, S., Eldering, A., Goldman, A., Shephard, M. W., Gunson, M., and Lampel, M.: TES carbon monoxide validation with DACOM aircraft measurements during INTEX-B 2006, J. Geophys. Res., 112, D24S48, https://doi.org/10.1029/2007JD008803, 2007a.
Luo, M., Rinsland, C. P., Rodgers, C. D., Logan, J. A., Worden, H., Kulawik, S., Eldering, A., Goldman, A., Shephard, M. W., Gunson, M., and Lampel, M.: Comparison of carbon monoxide measurements by TES and MOPITT: Influence of a priori data and instrument characteristics on nadir atmospheric species retrievals, J. Geophys. Res., 112, D09303, https://doi.org/10.1029/2006JD007663, 2007b.

Mao, H. and Talbot, R.: $\mathrm{O}_{3}$ and $\mathrm{CO}$ in New England: Temporal variations and relationships, J. Geophys. Res., 109, D21304, https://doi.org/10.1029/2004JD004913, 2004.

Mari, C., Jacob, D. J., and Bechtold, P.: Transport and scavenging of soluble gases in a deep convective cloud, J. Geophys. Res., 105, 22255-22267, 2000.

Mauzerall, D. L., Narita, D., Akimoto, H., Horowitz, L., Walters, S., Hauglustaine, D. A., and Brasseur, G.: Seasonal characteristics of tropospheric ozone production and mixing ratios over East Asia: A global three-dimensional chemical transport model analysis, J. Geophys. Res., 105, 17895-17910, https://doi.org/10.1029/2000JD900087, 2000.

Moorthi, S. and Suarez, M. J.: Relaxed Arakawa-Shubert. A Parameterization of moist convection for general circulation models, Mon. Weather Rev., 120, 978-1002, 1992.

Naja, M., Lal, S., and Chand, D.: Diurnal and seasonal variabilities in surface ozone at a high altitude site Mt Abu $\left(24.6^{\circ} \mathrm{N}\right.$, $72.7^{\circ} \mathrm{E}, 1680 \mathrm{~m}$ asl) in India, Atmos. Environ., 37, 4205-4215, https://doi.org/10.1016/S1352-2310(03)00565-X, 2003.

Nassar, R., Logan, J. A., Worden, H. M., Megretskaia, I. A., Bowman, K. W., Osterman, G. B., Thompson, A. M., Tarasick, D. W., Austin, S., Claude, H., Dubey, M. K., Hocking, W. K., Johnson, B. J., Joseph, E., Merrill, J., Morris, G. A., Newchurch, M., Oltmans, S. J., Posny, F., Schmidlin, F., Vömel, H., Whiteman, D. N., and Witte, J. C.: Validation of Tropospheric Emission Spectrometer (TES) nadir ozone profiles using ozonesonde measurements, J. Geophys. Res., 113, D15S17, https://doi.org/10.1029/2007JD008819, 2008.

Osterman, G. B., Kulawik, S. S., Worden, H., Richards, N. A., Fisher, B. M., Eldering, A., Shephard, M. W., Froidevaux, L., Labow, G., Luo, M., Herman, R. L., Bowman, K. W., and Thompson, A. M.: Validation of Tropospheric Emission Spectrometer (TES) measurements of the total, stratospheric, and tropospheric column abundance of ozone, J. Geophys. Res., 113, D15S16, https://doi.org/10.1029/2007JD008801, 2008.

Parrington, M., Jones, D. B. A., Bowman, K. W., Horowitz, L. W., Thompson, A. M., Tarasick, D. W., and Witte, J. C.: Estimating the summertime tropospheric ozone distribution over North America through assimilation of observations from the Tropospheric Emission Spectrometer, J. Geophys. Res., 113, D18307, https://doi.org/10.1029/2007JD009341, 2008.

Parrish, D. D., Holloway, J. S., Trainer, M., Murphy, P. C., Forbes, G. L., and Fehsenfeld, F. C.: Export of North American Ozone Pollution to the North Atlantic Ocean, Science, 259, 1436-1439, 1993.

Parrish, D. D., Trainer, M., Holloway, J. S., Yee, J. E., Warshawasky, M. S., and Fehsenfeld, F. C.: Relationships between ozone and carbon monoxide at surface sites in the North Atlantic region, J. Geophys. Res., 103, 13357-13376, 1998.

Real, E., Law, K. S., Schlager, H., Roiger, A., Huntrieser, H., Methven, J., Cain, M., Holloway, J., Neuman, J. A., Ryerson, T., Flocke, F., de Gouw, J., Atlas, E., Donnelly, S., and Parrish, 
D.: Lagrangian analysis of low altitude anthropogenic plume processing across the North Atlantic, Atmos. Chem. Phys., 8, 77377754, https://doi.org/10.5194/acp-8-7737-2008, 2008.

Rotman, D. A., Tannahill, J. R., Kinnison, D. E., Connell, P. S., Bergmann, D., Proctor, D., Rodriguez, J. M., Lin, S. J., Rood, R. B., Prather, M. J., Rasch, P. J., Considine, D. B., Ramaroson, R., and Kawa, Kawa, S. R.: Global Modeling Initiative assessment model: Model description, integration, and testing of the transport shell, J. Geophys. Res., 106, 1669-1691, 2001.

Schoeberl, M. R., Duncan, B. N., Douglass, A. R., Waters, J., Livesey, N., Read, W., and Filipiak, M.: The carbon monoxide tape recorder, Geophys. Res. Lett., 33, L12811, https://doi.org/10.1029/2006GL026178, 2006.

Seinfeld, J. H. and Pandis, S. N.: Atmospheric Chemistry and Physics, Wiley, New York, 1998.

Shim, C., Li, Q., Luo, M., Kulawik, S., Worden, H., Worden, J., Eldering, A., Diskin, G., Sachse, G., Weinheimer, A., Knapp, D., Montzca, D., and Campos, T.: Satellite observations of Mexico City pollution outflow from the Tropospheric Emissions Spectrometer (TES), Atmos. Environ., 43, 1540-1547, https://doi.org/10.1016/j.atmosenv.2008.11.026, 2009.

Shindell, D. T., Faluvegi, G., Stevenson, D. S., Krol, M. C., Emmons, L. K., Lamarque, J.-F., Pétron, G., Dentener, F. J., Ellingsen, K., Schultz, M. G., Wild, O., Amann, M., Atherton, C. S., Bergmann, D. J., Bey, I., Butler, T., Cofala, J., Collins, W. J., Derwent, R. G., Doherty, R. M., Drevet, J., Eskes, H. J., Fiore, A. M., Gauss, M., Hauglustaine, D. A., Horowitz, L. W., Isaksen, I. S. A., Lawrence, M. G., Montanaro, V., Müller, J.-F., Pitari G., Prather, M. J., Pyle, J. A., Rast, S., Rodriguez, J. M., Sanderson, M. G., Savage, N. H., Strahan, S. E., Sudo, K., Szopa, S., Unger, N., van Noije, T. P. C., and Zeng, G: Multimodel simulations of carbon monoxide: Comparison with observations and projected near-future changes, J. Geophys. Res., 111, D19306, https://doi.org/10.1029/2006JD007100, 2006.

Strahan, S. E., Duncan, B. N., and Hoor, P.: Observationally derived transport diagnostics for the lowermost stratosphere and their application to the GMI chemistry and transport model, Atmos. Chem. Phys., 7, 2435-2445, https://doi.org/10.5194/acp-72435-2007, 2007.

Thompson, A. M., Pickering, K. E., McNamara, D. P., Schoeberl, M. R., Hudson, R. D., Kim, J. H., Browell, E. V., Kirchhoff, V. W. J. H., and Nganga, D.: Where did tropospheric ozone over southern Africa and the tropical Atlantic come from in October 1992? Insights from TOMS, GTE TRACE A, and SAFARI 1992, J. Geophys. Res., 101, 24251-24278, https://doi.org/10.1029/96JD01463, 1996.

Thompson, A. M., Witte, J. C., Smit, H. G. J., Oltmans, S. J., Johnson, J. B., Kirchhoff, V. W. J. H., and Schmidlin, F. J.: Southern Hemisphere Additional Ozonesondes (SHADOZ) 1998-2000 tropical ozone climatology - 1. Comparison with Total Ozone Mapping Spectrometer (TOMS) and ground-based measurements, J. Geophys. Res., 108, 8238, https://doi.org/10.1029/2001JD000967, 2003.

Tsutsumi, Y., and Matsueda, H.: Relationship of ozone and $\mathrm{CO}$ at the summit of Mt. Fuji $\left(35.35^{\circ} \mathrm{N}, 138.73^{\circ} \mathrm{E}, 3776 \mathrm{~m}\right.$ above sea level) in summer 1997, Atmos. Environ., 34, 553-561, 2000.
Voulgarakis, A., Telford, P. J., Aghedo, A. M., Braesicke, P., Faluvegi, G., Abraham, N. L., Bowman, K. W., Pyle, J. A., and Shindell, D. T.: Global multi-year $\mathrm{O}_{3}-\mathrm{CO}$ correlation patterns from models and TES satellite observations, Atmos. Chem. Phys., 11, 5819-5838, https://doi.org/10.5194/acp-11-5819-2011, 2011.

Wang, T., Wong, H. L. A., Tang, J., Ding, A., Wu, W. S., and Zhang, X. C.: On the origin of surface ozone and reactive nitrogen observed at a remote mountain site in the northeastern QinghaiTibetan Plateau, western China, J. Geophys. Res., 111, D08303, https://doi.org/10.1029/2005JD006527, 2006.

Worden, J., Kulawik, S. S., Shephard, M. W., Clough, S. A., Worden, H., Bowman, K., and Goldman, A.: Predicted errors of tropospheric emission spectrometer nadir retrievals from spectral window selection, J. Geophys. Res., 109, D09308, https://doi.org/10.1029/2004JD004522, 2004.

Worden, H. M., Logan, J. A., Worden, J. R., Beer, R., Bowman, K., Clough, S. A., Eldering, A., Fisher, B. M., Gunson, M. R., Herman, R. L., Kulawik, S. S., Lampel, M. C., Luo, M., Megretskaia, I. A., Osterman, G. B., and Shephard, M. W.: Comparisons of Tropospheric Emission Spectrometer (TES) ozone profiles to ozonesondes: Methods and initial results, J. Geophys. Res., 112, D03309, https://doi.org/10.1029/2006JD007258, 2007.

Yevich, R. and Logan, J. A.: An assesment of biofuel use and burning of agricultural waste in the developing world, Global Biogeochem. Cy., 17, 1095, https://doi.org/10.1029/2002GB001952, 2003.

Zhang, G. J. and McFarlane, N. A.: Sensitivity of climate simulations to the parameterization of cumulus convection in the Canadian Climate Centre general circulation model, Atmos. Ocean., 33, 407-446, 1995.

Zhang, L., Jacob, D. J., Bowman, K. W., Logan, J. A., Turquety, S., Hudman, R. C., Li, Q., Beer, R., Worden, H. M., Rinsland, C. P., Kulawik, S. S., Lampel, M. C., Shephard, M. W., Fisher, B. M., Eldering, A., and Avery, M. A.: Ozone$\mathrm{CO}$ correlations determined by the TES satellite instrument in continental outflow regions, Geophys. Res. Lett., 33, L18804, https://doi.org/10.1029/2006GL026399, 2006.

Zhang, L., Li, Q. B., Jin, J., Liu, H., Livesey, N., Jiang, J. H., Mao, Y., Chen, D., Luo, M., and Chen, Y.: Impacts of 2006 Indonesian fires and dynamics on tropical upper tropospheric carbon monoxide and ozone, Atmos. Chem. Phys., 11, 10929-10946, https://doi.org/10.5194/acp-11-10929-2011, 2011.

Zhang, L., Li, Q. B., Murray, L. T., Luo, M., Liu, H., Jiang, J. H., Mao, Y., Chen, D., Gao, M., and Livesey, N.: A tropospheric ozone maximum over the equatorial Southern Indian Ocean, Atmos. Chem. Phys., 12, 4279-4296, https://doi.org/10.5194/acp12-4279-2012, 2012.

Ziemke, J. R., Chandra, S., Duncan, B. N., Froidevaux, L., Bhartia, P. K., Levelt, P. F., and Waters, J. W.: Tropospheric ozone determined from Aura OMI and MLS: Evaluation of measurements and comparison with the Global Modeling Initiative's Chemical Transport Model, J. Geophys. Res., 111, D19303, https://doi.org/10.1029/2006JD007089, 2006. 